http://doi.org/http://doi.org/10.11646/zootaxa.4150.1.2

http://zoobank.org/urn:lsid:zoobank.org:pub:39FEFD12-7D8C-4596-BA4A-1D147439EB31

\title{
Re-description of Orchestia stephenseni Cecchini, 1928: designation of neotype and senior synonym to Orchestia constricta A. Costa, 1853 (Crustacea: Amphipoda: Talitridae) by Reversal of Precedence
}

\author{
DAVIDE IACIOFANO \& SABRINA LO BRUTTO ${ }^{1}$ \\ Dept. STeBiCeF, Section of Animal Biology, University of Palermo, via Archirafi 18, Palermo, (Italy) \\ ${ }^{1}$ Corresponding author. E-mail: sabrina.lobrutto@unipa.it
}

\begin{abstract}
The beach flea Orchestia stephenseni was originally described by Cecchini (1928), and successively by Karaman (1973). The description of this species will be herein revised by focusing on the variation of the gnathopod 2 in males, as detected during its growth period. An analysis of DNA Barcoding was performed to support the assignment of the taxonomic species to five morphotypes. As the type specimen has not yet been designated, a neotype is assigned. The name of the species is here presented as a valid name as it satisfies the requirements of a Reversal of the Principle of Priority: Orchestia stephenseni takes precedence over the objective synonym Orchestia constricta A. Costa, 1853, in accordance with Article 23.9.2. of the International Code of Zoological Nomenclature. Orchestia stephenseni Cecchini, 1928 becomes nomen protectum, and Orchestia constricta nomen oblitum. The results presented in this paper also support the status of Orchestia stephenseni as a Mediterranean endemic species, thereby rejecting previous Atlantic records. The synonymies for $O$. stephenseni are revised accordingly.
\end{abstract}

Key words: Amphipoda, Talitridae, Orchestia stephenseni, marine beach flea, DNA Barcoding

\section{Introduction}

A knowledge of marine talitrid amphipods is important for ecological (Davolos et al. 2005; Fanini et al. 2005; Deidun et al. 2007; Ugolini et al. 2008) and biodiversity monitoring studies (Lo Brutto et al. 2013), and the correct identification at the species level is essential for conservation strategies.

Historically, the talitrid species have been placed into two genera: Orchestia Leach, 1814 and Talorchestia Dana, 1853. The genus Orchestia was delimited as a supralittoral Atlantic-Mediterranean group (Bousfield 1982), which was arranged into approximately twenty species from different habitats.

Five Orchestia species inhabit the supralittoral of the Mediterranean Sea: O. montagui Audouin, 1826 living in the banquette of Posidonia oceanica (L.) Delile and on mixed sand and coarse gravel beaches (Lowry \& Fanini 2013); O. xylino Lowry \& Fanini, 2013 living on mixed sand, coarse gravel and boulder stone beaches (Lowry \& Fanini 2013); $O$. mediterranea A. Costa, 1853 living under $P$. oceanica debris, far from the sea (Vecchi 1931); $O$. gammarellus (Pallas, 1766) living on sea shores, occasionally far from the sea (Chevreux 1911); and $O$. stephenseni Cecchini, 1928 living on the seashore under stone, under P. oceanica and in the river mouth (Karaman 1973). The common Mediterranean assemblages are usually composed of three syntopic Orchestia species: $O$. stephenseni, O. montagui and O. mediterranea; and O. stephenseni seems to be dominant (Prato et al. 1995).

Orchestia stephenseni has been described by Cecchini (1928), and the description revised by Karaman (1973). Both descriptions used specimens larger than $18 \mathrm{~mm}$ and, although the peraeopod 7 displayed the same shape, the gnathopod 2 in males had two different shapes. The gnathopod 2 shape described by Cecchini (1928) was the only one to be reported in the Manual by Ruffo ed. (1993), and commonly used for identifying species throughout the field of Mediterranean studies. Although quoted in various articles (e.g. Lowry \& Fanini 2013), the work by Karaman (1973) is not widely used in the identification of Mediterranean species. As a result, there is a paucity of 
information relating to the distribution of conspecifics. These two shapes have been recorded in a population sampled in the central Mediterranean (i.e. this paper) and they are referred to as the "Cecchini-shape", corresponding to the herein called Morphotype IV, and the "Karaman-shape" to Morphotype V.

A lack of previous descriptions of the mouthparts of $O$. stephenseni led us to revise the description of the species, to include individuals whose lengths were from 11 to $21 \mathrm{~mm}$. A morphological, taxonomic approach is integrated with DNA barcoding as a molecular tool. Within the population under investigation in this paper, a variation with growth in the gnathopod 2 male will be demonstrated and the molecular dataset which is herein presented will attempt to support species identification.

Analysing the growth stages of $O$. stephenseni, a second species $O$. constricta A. Costa, 1853 was identified as being conspecific. The name $O$. constricta is not widely applied within the literature. In order to stabilize the Mediterranean talitrid taxonomy, $O$. stephenseni is here presented as an accepted name as it satisfies the requirements of a Reversal of the Principle of Priority. Orchestia stephenseni takes precedence over the objective synonym $O$. constricta, in accordance with Article 23.9.2. of the International Code of Zoological Nomenclature. Orchestia stephenseni Cecchini, 1928 becomes nomen protectum, and the less circulated senior synonym Orchestia constricta A. Costa, 1853 is designated as nomen oblitum. The results presented in this paper also support the hypothesis of $O$. stephenseni as a Mediterranean endemic species. Thus the previous records of $O$. stephensen $i$ from the Atlantic coast are rejected and the synonymy for the species is updated to reflect this hypothesis.

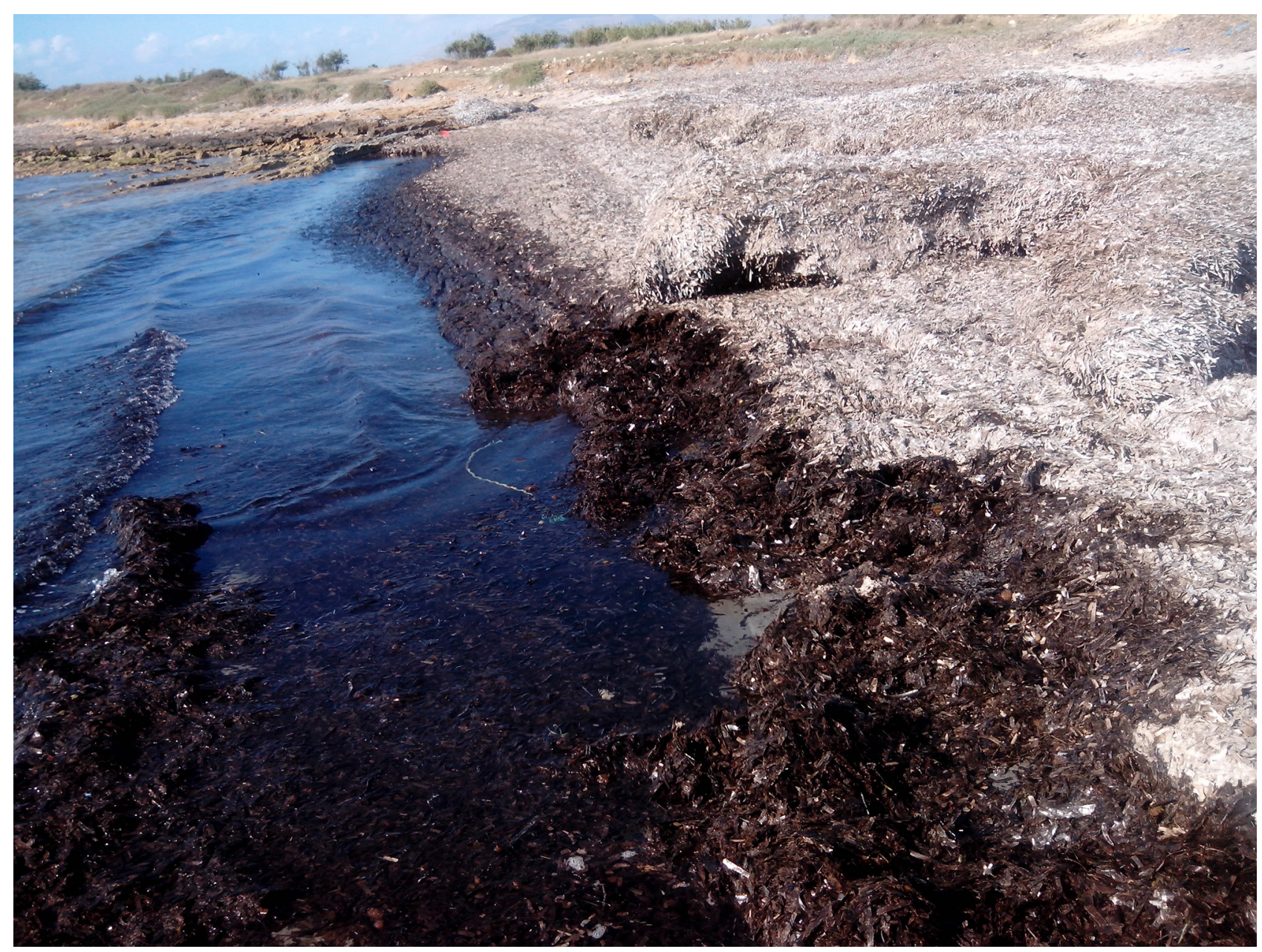

FIGURE 1. Sample site: banquette of Posidonia oceanica (L.) Delile, at the Stagnone of Marsala (western Sicily, southern Italy, central Mediterranean Sea).

\section{Materials and methods}

Sampling. This study is based upon material collected from the banquette of P. oceanica (Figure 1) of the Stagnone 
di Marsala lagoon, Sicily, southern Italy $\left(37^{\circ} 55^{\prime} 03.83^{\prime \prime N}\right.$; $12^{\circ} 28^{\prime} 10.98^{\prime \prime}$ ) in May 2013. The specimens, which were collected in association with $O$. montagui and $O$. mediterranea in banquette of $P$. oceanica, could be ascribed to O. stephenseni Cecchini, 1928 (onward named Morphotype IV), others were ascribable to O. stephenseni Karaman, 1973 (Morphotype V) and other specimens identified as O. cf. stephenseni, the latter with an unusual shape of gnathopod 2 (Morphotype I, II and III) (Figure 2). The samples were collected using hand-nets and then carefully transferred into plastic containers and fixed in $95 \%$ ethanol. A neotype is preserved in the permanent archives of the Zoological Museum collections (University of Palermo, Italy) together with the organic DNA extracted, identifiable by the Voucher Number MZPA-AMPH-N_0002.

Biometric data and Iconography. Fifty-three specimens were examined under a stereo-microscope and later selected for dissection. In order to ensure precise measurements, the specimens were placed on graph paper and photographed (FINEPIX S1800, FUJIFILM). The length of the specimens was measured from head to telson using ImageJ software (Rasband 2008); the flagellum articles of antenna 2 were also counted as an estimate of growth throughout the moulting period. Differences between dry and wet specimens were observed. Some specimens were photographed in humid form and the photographs were then repeated after complete dehydration. A comparison of the measurements revealed that wet specimens were greater than dry measurements. It was, therefore, decided to proceed with wet specimens as these reporting measures were most similar to live individuals. Appendages of the dissected specimens were examined and illustrations produced using a Leica 4000B light microscope with camera lucida. All illustrations were drawn with pencil, then retraced with iron-gall ink and finally converted to digital form at 1200dpi resolution.

Extraction of DNA and amplification of mtCOI gene. Total genomic DNA extraction was performed on fixed specimens, after having dried them on paper using the Genomic DNA Extraction Kit Tissue (RBCBioscience, Taiwan). A 630-bp fragment of the target mitochondrial (mt) cytochrome oxidase subunit I (COI) was amplified using the primer pairs LCO-1490 (5'-GGTCAACAAATCATAAAGATATTGG-3) and HCO-2198 (5'TAAACTTCAGGGTGACCAAAAAATCA-3') (Folmer et al. 1994). PCR was performed in a $25 \mu \mathrm{L}$ volume containing $1 \times$ Incomplete $\mathrm{NH}_{4}$ Reaction buffer, $4 \mathrm{mM} \mathrm{MgCl}, 0.2 \mathrm{mM}$ dNTP, $2.5 \mathrm{U}$ Taq polymerase (Bioron GmbH, Germany), $1 \mu \mathrm{M}$ of each primer, 80-100 ng of DNA template.

Cycling conditions for PCR amplifications consisted of an initial $95^{\circ} \mathrm{C}$ denaturation step for 5 minutes followed by 35 cycles of $60 \mathrm{sec}$ at $95^{\circ} \mathrm{C}, 60 \mathrm{sec}$ at $46^{\circ} \mathrm{C}$, and $60 \mathrm{sec}$ at $72^{\circ} \mathrm{C}$, with a final extension at $72^{\circ} \mathrm{C}$ for 8 min and a final cooling at $4^{\circ} \mathrm{C}$. The resulting amplified DNA fragments were purified with the QIAquick PCR Purification Kit (Qiagen, Germany) and then sequenced with an Applied Biosystems (ABI) 3730xl DNA analysis. Sequences were deposited in GenBank with the Accession Numbers (A.N.) shown in Table 1.

TABLE 1. Details of COI reference sequences of Orchestia species used in the NJ tree.

\begin{tabular}{lll}
\hline Accession Number (A.N.) & Sampling locality & Reference \\
\hline Orchestia gammarellus & Atlantic Ocean (NW Iceland) & Henzler \& Ingólfsson 2007 \\
EU276207 & Atlantic Ocean (English Channel) & Henzler \& Ingólfsson 2007 \\
Orchestia mediterranea & & \\
KR827689 & Mediterranean Sea (Sicily, Italy) & This paper \\
Orchestia montagui & & \\
JQ390313 & Mediterranean Sea (Gozo, Malta) & Pavesi et al. 2012 \\
JQ390319 & Mediterranean Sea (Latium, Italy) & Pavesi et al. 2012 \\
JQ390326 & Mediterranean Sea (Apulia, Italy) & Pavesi et al. 2012 \\
JQ390332 & Mediterranean Sea (Sardinia, Italy) & Pavesi et al. 2012 \\
KR827690 & Mediterranean Sea (Sicily, Italy) & This paper \\
Orchestia stephenseni & & \\
JX094885 & & Wildish et al. 2012 \\
KR827687 (Morphotype I, III and V) & Mediterranean Sea (Sicily, Italy) & This paper \\
KR827688 (Morphotype II and IV) & Mediterranean Sea (Sicily, Italy) & This paper \\
\hline
\end{tabular}


Mitochondrial sequences of the voucher specimens of $O$. stephenseni were compared with sequences of the congeneric syntopic species which had been sampled and deposited in the GenBank (http://www.ncbi.nlm.nih.gov) database (see Table 1 for details). A reference sequence of $O$. gammarellus (Pallas 1766) was used as an outgroup. Sequence analyses were performed with MEGA version 6 (Tamura et al. 2013). Nucleotide sequences were aligned by the ClustalW model (Thompson et al. 1994) with default settings. Cluster analysis was performed using Kimura-2-Parameter distance (K2P; Kimura 1980) and Neighbour-Joining method (NJ; Saitou \& Nei 1987).

Terminology. The general terminology of amphipod morphology follows that documented in Ruffo ed. (1993). The definition of setae and spines follows Watling (1989) which defines 'seta' as an articulated, cuticular extension of any shape or size, and 'spine' is a non-articulated cuticular extension which has a base generally narrower than the length of the structure. Different kinds of setae have been observed and reported in this revised description of $O$. stephenseni. Some have already been classified and clearly reviewed by Watling (1989) (i.e. 'Plumose seta', 'Simple seta', 'Tooth seta'); unclassified setae include 'Bifid seta', seta with a bifid apex, with two curved tips (Figure 3), and 'Peduncular spine-like seta', a 'strong spine' on the hyalids peduncle of Uropod 1, previously observed by Bousfield \& Hendrycks (2002).

Abbreviations. A1: first antenna (antennula). A2: second antenna (antenna). Lbr: upper lip (labrum). Md: mandible. Lb: lower lip (labium). Mx1: first maxilla (maxillula). Mx2: second maxilla (maxilla). Mxp: maxilliped. Cx 1-7: coxal plates of the first to the seventh peraeopod. Gn1: first gnathopod. Gn2: second gnathopod. P3-P7: third to seventh peraeopods. PI1-P13: first to third pleopods. Ep1-Ep3: first to third epimeral plates. U1-U3: first to third uropods. T: telson.

Acronym for Museums: MZPA, for Zoological Museum of the University of Palermo (Italy).

\section{Results}

Variation in shape. Of a total of 53 male specimens examined, the development of gnathopod 2 could be ascribed to five morphotypes, which were designated as: Morphotype I, Morphotype II, Morphotype III, Morphotype IV and Morphotype V (Figure 2). The specimens also displayed a very slight variation in the merus and carpus of the peraeopod 7: the merus and carpus were very slim in the smallest specimens whilst the merus and carpus were barely dilated in the largest specimens. Specimens also showed a variation in the shape of the 'cusp' (sensu Bousfield \& Hendrycks 2002) on the coxa 2 posterior margin, which become more acute during growth. However, only the variation in the propodus and dactylus of gnathopod 2 was significantly visible throughout the growth period. The five morphotypes corresponded to different body lengths. Morphotype I was associated to the smallest body length sampled and successive morphotypes were associated to larger specimens (Figure 2). Figure 4 shows the frequency of the five shapes in the population in relation to their body length.

In order to search for a correlation between body length and number of moults, the number of antenna 2 flagellar articles were counted, as a discrete growth parameter. Indeed, the number of flagellar articles has often been expected to increase $x$-fold for each moult (Nair \& Anger 1979). Unfortunately, no discrete size-class was discriminated (Table 2) and no association with one or more moult steps was observed. However, it cannot be excluded that the transition from one shape to another requires more than one moult. Body length varied from 11.12 to $21.31 \mathrm{~mm}$ and it was proportional to the number of flagellar articles of the antenna 2, i.e. varying from 17 to 25. Various specimens were asymmetrical in the number of flagellar articles of antenna 2; in these cases, we considered the highest number. A significant linear correlation between the number of flagellar articles of antenna 2 and body-length was scored, with an $\mathrm{R}^{2}$ value of 0.7166 and $p<0.001$ (Figure 5). It is noteworthy to point out that a difference in body length was detected between dry and wet specimens. This measurement, performed in 95\% ethanol and after complete drying, revealed differences in body-length for twenty-four specimens; a 'dry length' was found to be smaller than a 'wet length', by approximately an average of $12 \%$.

Molecular analysis. In order to support species identification, the mtCOI of five specimens, ascribable each to one of the five morphotypes, was sequenced. A total of 630 base pairs (bp) of COI was aligned and compared with cogeneric reference species (Table 1). Intra-species K2P distances ranged from $0.0 \%$ to $2.3 \%$ for all COI barcodes, and the inter-species K2P distances ranged from $11.5 \%$, to $22.3 \%$, resulting in no overlap between the two levels of variation. The COI sequences of the Sicilian $O$. stephenseni specimens matched the only $O$. stephenseni reference sequence available (A.N. JX094885). Concurrently, the syntopic O. montagui matched the 

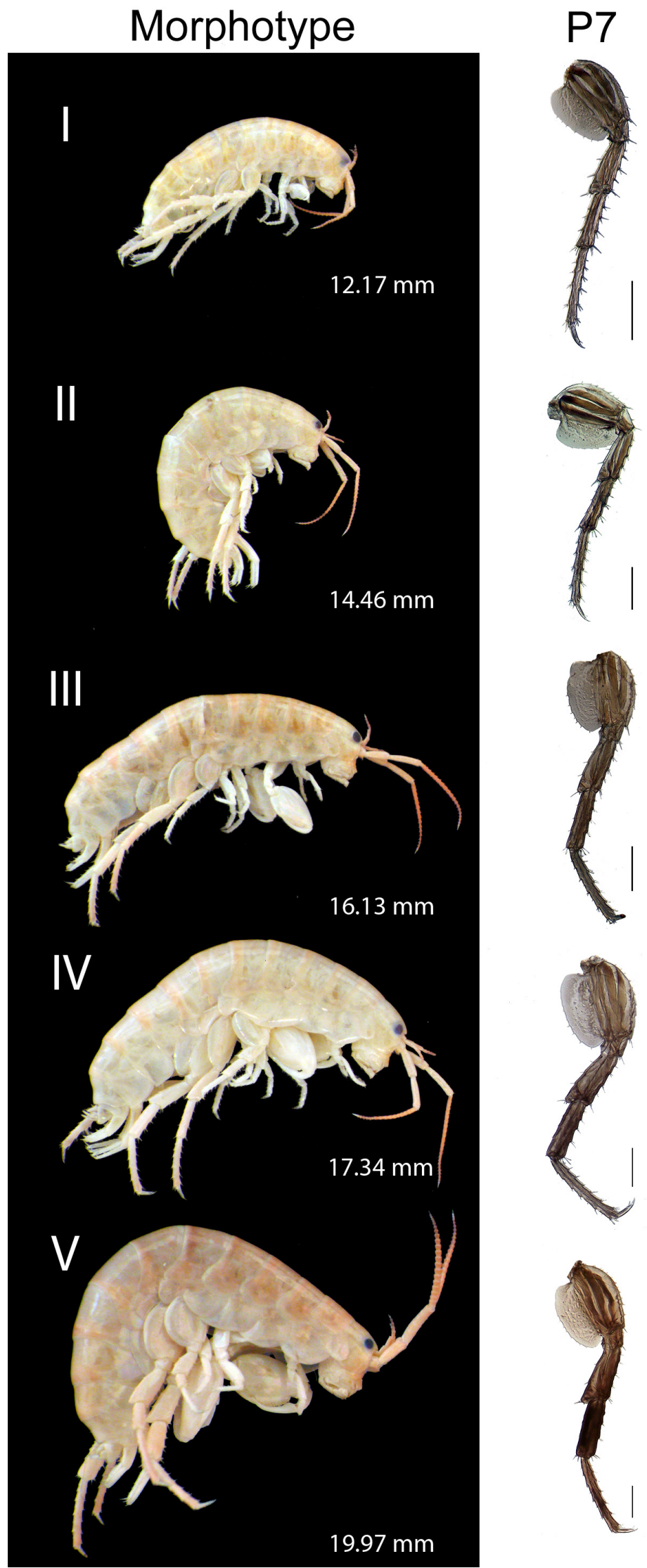

\section{Gn2}
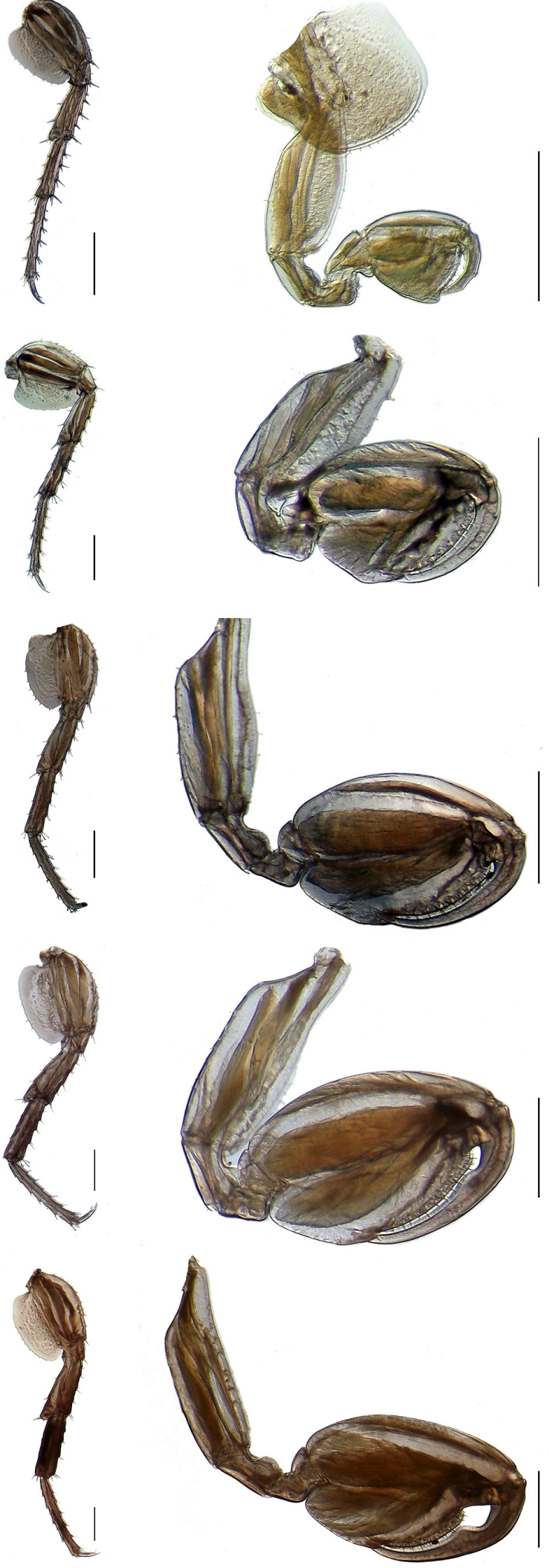

FIGURE 2. The five $O$. stephenseni morphotypes, named Morphotype $\mathrm{I}$ to $\mathrm{V}$, and corresponding to the five gnathopod 2 shapes. The body-length for each photographed individual is reported. Scale bar $=1 \mathrm{~mm}$. 


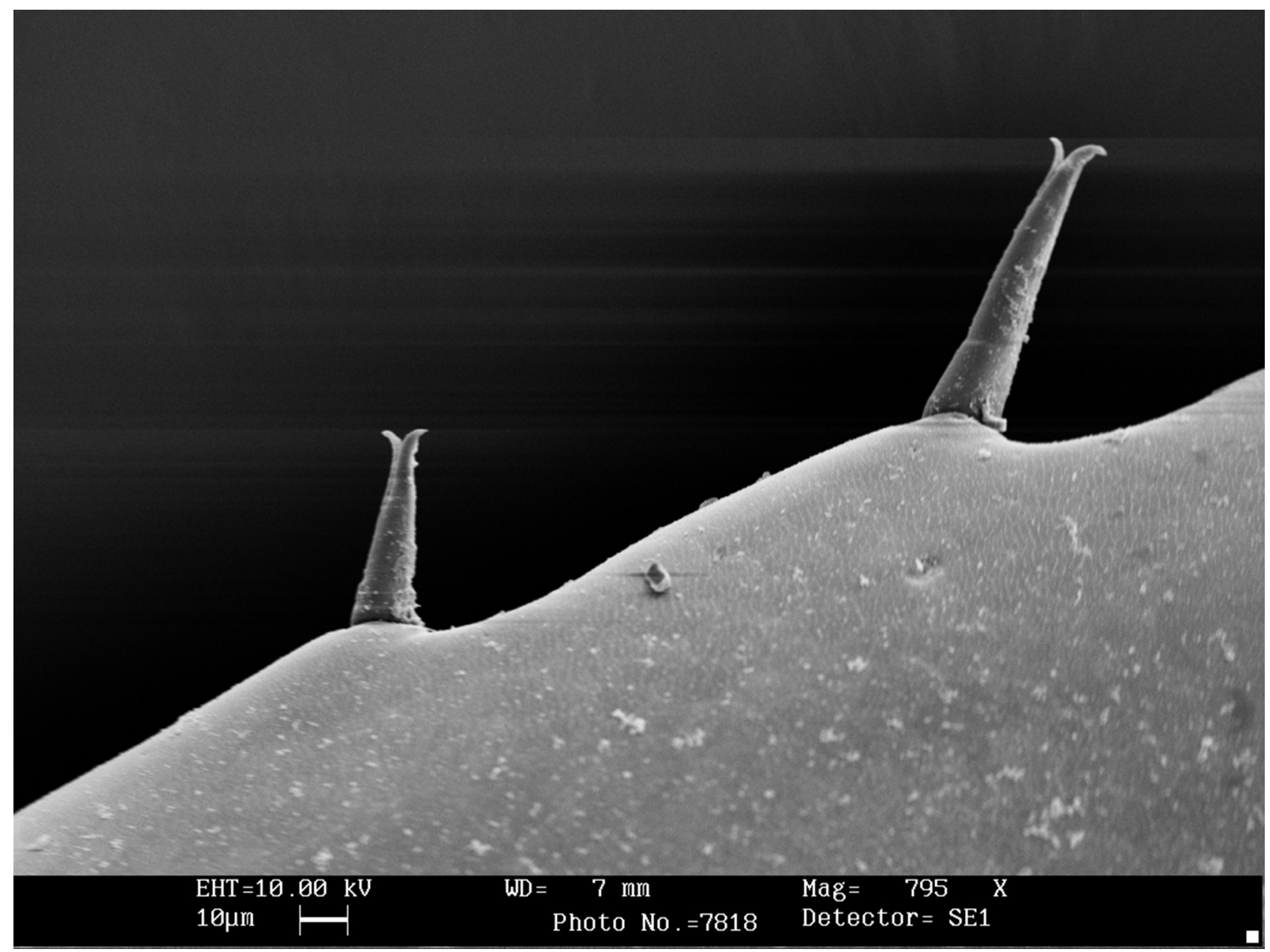

FIGURE 3. Orchestia stephenseni Cecchini, 1928. Example of Bifid setae on peraeopods (see text). SEM (Scanning Electron Microscope) photograph.

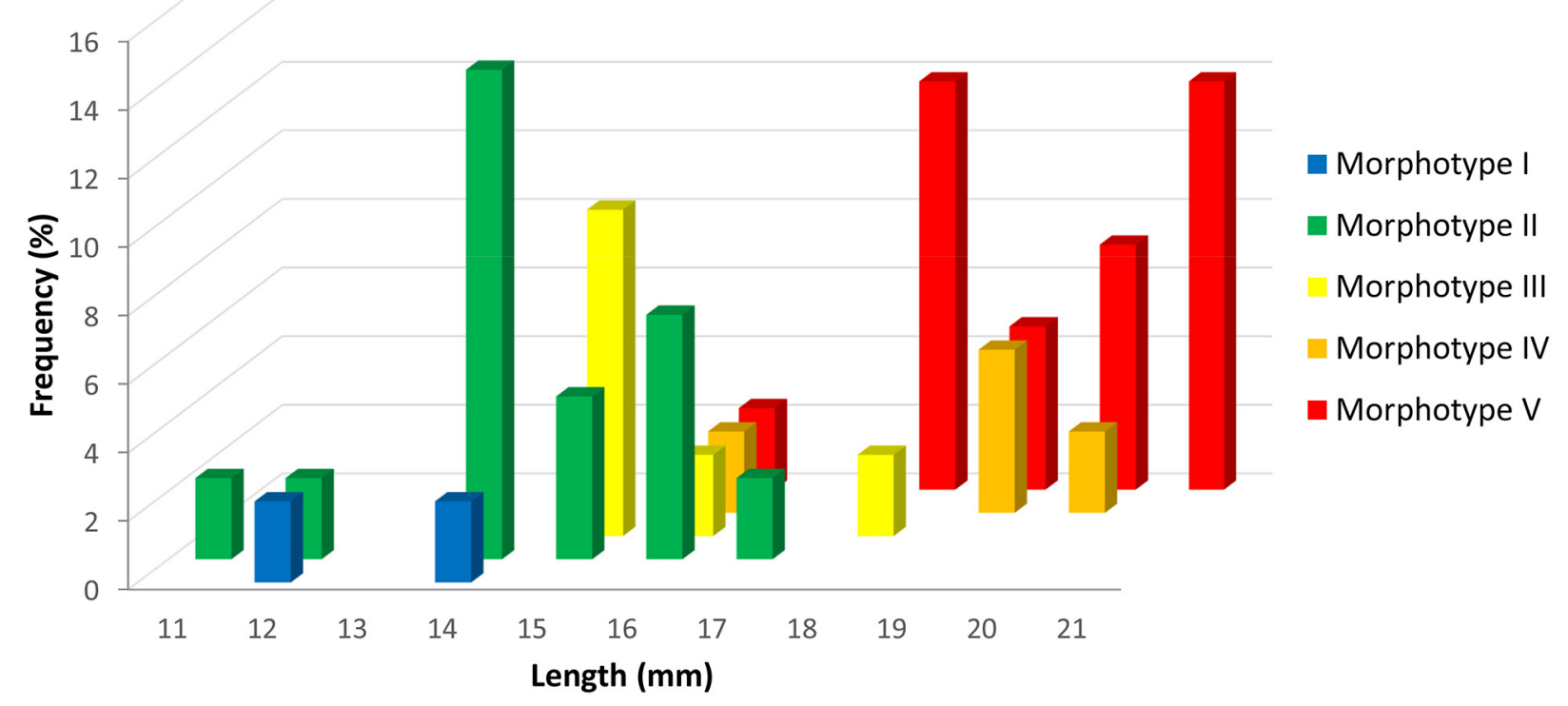

FIGURE 4. Frequency of Morphotypes along body-length (the length has been rounded to the nearest integer). 


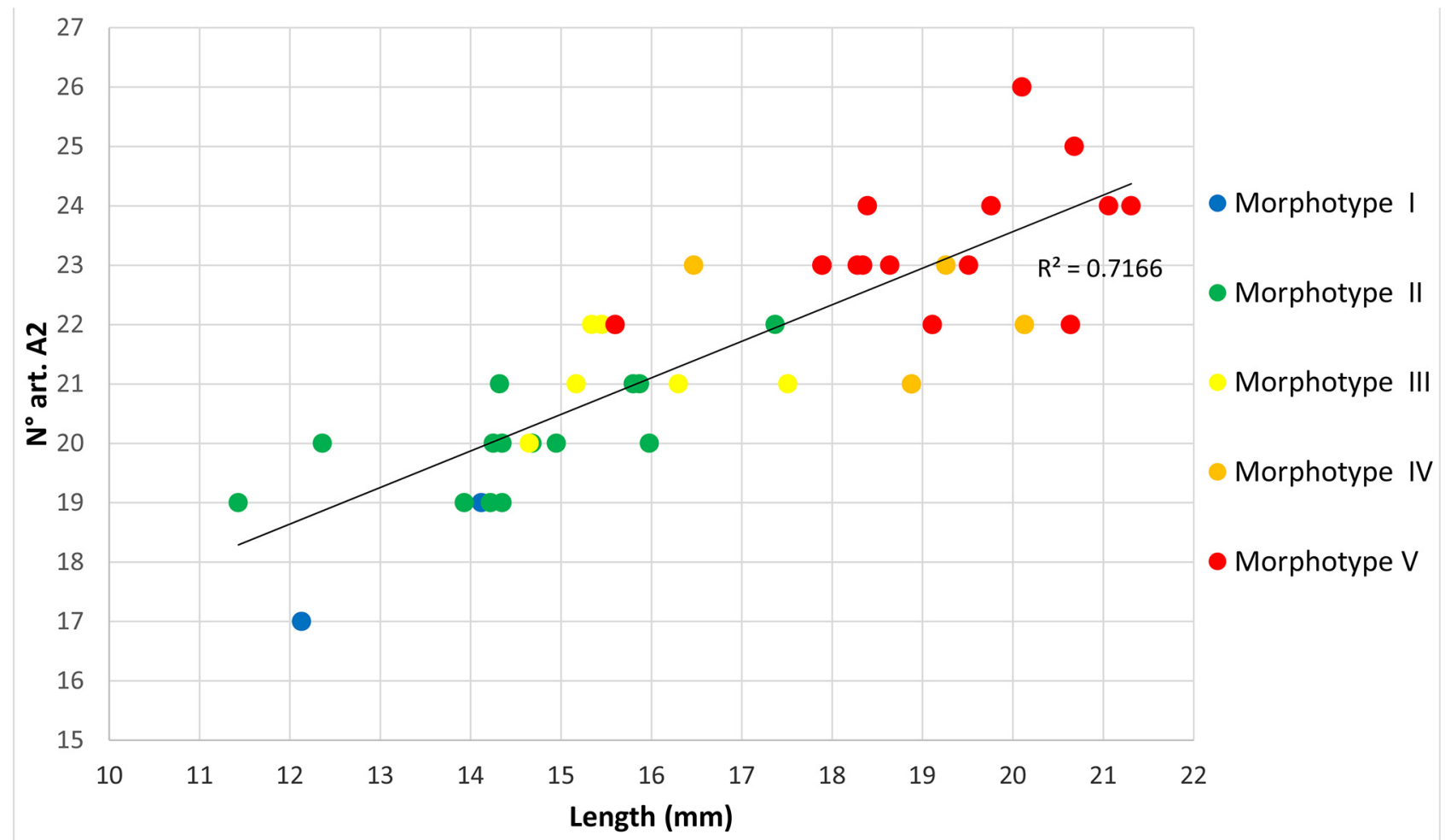

FIGURE 5. Linear regression between body length and number of antenna 2 flagellar articles for each Morphotype.

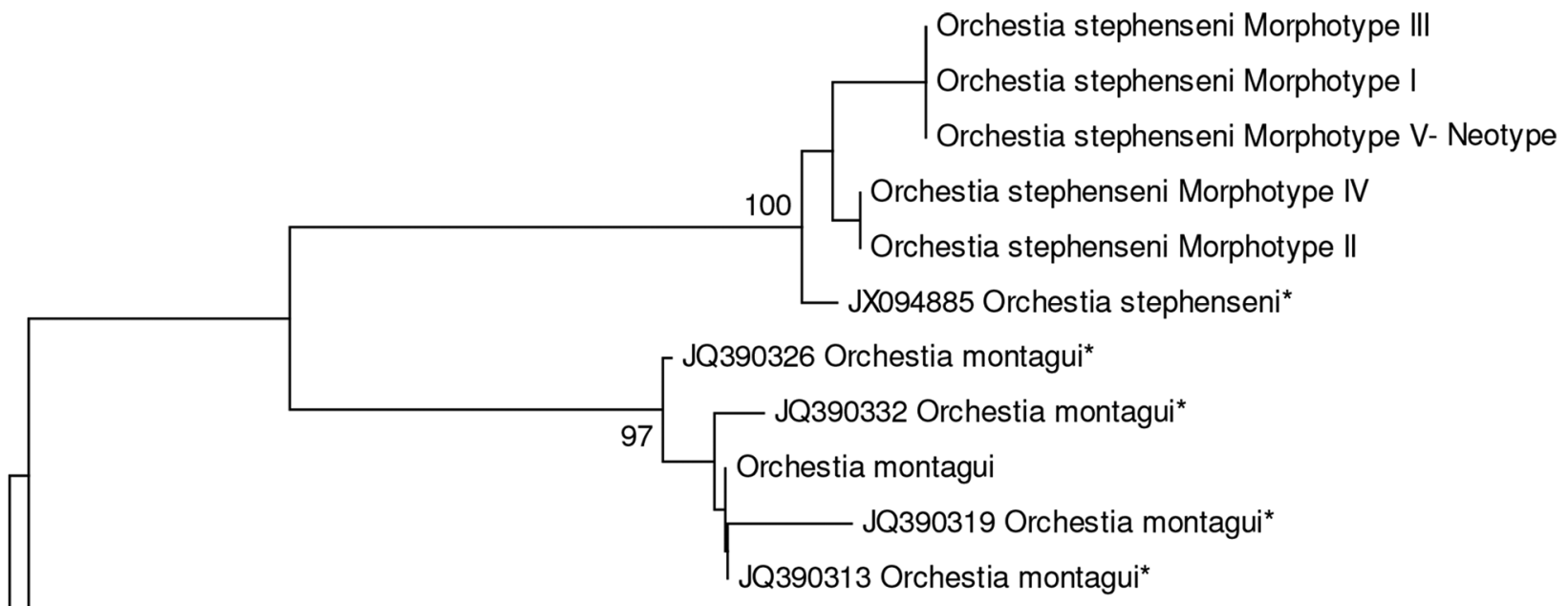

Orchestia mediterranea

EU276380 Orchestia gammarellus*

100 EU276207 Orchestia gammarellus*

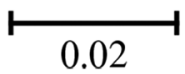

FIGURE 6. $\mathrm{NJ}$ tree constructed on the K2P model performed with 630-bp COI sequences, including sequences of the five $O$. stephenseni shapes, the Sicilian O. montagui and O. mediterranea samples, and sequences reference $(*)$ from GenBank (shown with the A.N.). The values allocated to the nodes were those calculated on 1,000 bootstrap replicates.

O. montagui sequences deposited in GenBank (Figure 6) while the first $O$. mediterranea sequence, here performed, set up its own separate clade (Figure 6). The NJ tree displayed the genetic cohesion of the Orchestia species sequenced in this research, supporting the hypothesis that the molecular discrimination approach is a powerful tool to be integrated into morphological description. 
TABLE 2. Range of body length and number of antenna 2 flagellar articles for the five Morphotypes.

\begin{tabular}{lll}
\hline & Body Length $(\mathrm{mm})$ & $\mathrm{N}^{\circ} \mathrm{A} 2$ art. \\
\hline Morphotype I & $13.12 \pm 1$ & $18 \pm 1$ \\
Morphotype II & $14.56 \pm 2.81$ & $20.5 \pm 1.5$ \\
Morphotype III & $15.73 \pm 1.77$ & $21 \pm 1$ \\
Morphotype IV & $18.68 \pm 1.45$ & $22 \pm 1$ \\
Morphotype V & $19.15 \pm 2.16$ & $24 \pm 2$ \\
\hline
\end{tabular}

\title{
Re-description
}

\author{
Suborder Senticaudata Lowry \& Myers, 2013 \\ Infraorder Talitrida Rafinesque, 1815 \\ Superfamily Talitroidea Bulycheva, 1957 \\ Family Talitridae Rafinesque, 1815 \\ Genus Orchestia Leach, 1814
}

\section{Orchestia stephenseni Cecchini, 1928}

(Figure 7,8)

Orchestia Stephenseni Cecchini, 1928: 7, pl. 2, fig. 3.-Cecchini 1929: 11.-Ruffo 1951: 1.

Orchestia ghigii Vecchi, 1929: 249, figs 1-5.-Maccagno 1939: 11.-Mateus \& Mateus 1959: 44.

Orchestia Ghigii.-—Ruffo 1937: 39.—Ruffo 1949: 323.

Orchestia stephenseni.-G. Karaman 1970: 32.-G. Karaman 1973: 137, figs 1-3.—Koukouras \& Russo 1991: 306, table 6.Bellan-Santini 1993: 752, fig. 515 (key).-Prato, Pastore \& Pavia 1995: 63, table 2.--Ruffo 1995: 43.-Stefanidou \& Voultsiadou-Koukoura 1995: 603, table 1.-De Matthaeis, Ketmaier, Davolos \& Cobolli 1999: 95 (genetics).-Ariani, Camassa \& Wittman 2000: 7, 12.-De Matthaeis, Davolos, Cobolli \& Ketmaier 2000: 1607 (table 1), 1611, table 4 (genetics).-Zavodnik \& Kovačić 2000: 338.-Cezgin, Kocataş \& Katağan 2001: 59, tables 2, 3.—Colombini, Chelazzi \& Fallaci 2002: 863.—Davolos, Ketmaier, Cobolli \& De Matthaeis 2002: 33 (genetics).—Fišer 2002: 38. -Davolos, Iannilli, De Matthaeis \& Pietrangeli 2005: 72, fig. 4.—Deidun, Saliba \& Schembri 2007: 456 (ecology).—Deidun \& Schembri 2008: 19 (ecology).—Akbulut, Ustaoğlu \& Çelik 2009: 51, table 1.—Deidun, Saliba \& Schembri 2009: 411 (ecology).— Zakhama-Sraieb, Sghaier \& Charfi-Cheikhrouha 2009: 5, table 3.-Lucena-Moya, Abraín, Pardo, Hermida \& Domínguez 2010: 7.- Sezgin \& Aydemir Çil 2010: 9, table 1.-Grintsov 2011: 143 (morphology).-Jelassi, Khemaissia \& NasriAmmar 2012: 383 (ecology).—Jelassi \& Nasri-Ammar 2012: 437 (ecology).

Orchestia constricta Costa, A., 1857: 183 (type locality: Terra d Otranto, Italy).—Heller 1866: 3.—Stebbing $1906: 542$.

Type material. Neotype, male, $21.31 \mathrm{~mm}$, MZPA-AMPH-N_0002, Stagnone of Marsala, Sicily (3755'03”N; $12^{\circ} 28^{\prime} 11^{\prime}$ 'E), among, inside and around banquettes of $P$. oceanica, July 2013, mediolittoral, hand collected.

Additional material examined. Fifty-three males, MZPA-AMPH-S_0002. Stagnone of Marsala, Sicily $\left(37^{\circ} 55^{\prime} 03^{\prime} \mathrm{N} ; 12^{\circ} 28^{\prime} 11^{\prime} \mathrm{E}\right)$, among, inside and around banquettes of $P$. oceanica, July 2013, mediolittoral, hand collected.

Type locality. Stagnone of Marsala, Sicily, 3755'03'N; 12²8'11'”E.

Ecology. Mixed sand/gravel, banquette and cobble beaches (slow-drying substrate sensu Pérès \& Picard 1964).

Description. Based on neotype, male, $21.31 \mathrm{~mm}$, Morphotype V, MZPA-AMPH-N_0002.

Head as long as peraeonite 1. Eyes present, small, circular. Antenna 1 short, reaching peduncular article 4 of antenna 2; peduncle article 1 as long as wide, article 2 and 3, longer than wide, sub-equal in length; article 1 distoventral and disto-dorsal with one pairs of tooth setae, proximo-ventral with 2 setae in row; article 2 disto-ventral and disto-dorsal with one pair of tooth setae with middle 1 plumose setae, ventral margin with 2 setae; article 3 dorsal with one pairs of tooth setae with middle 1 plumose setae and disto-ventral with one pairs of tooth setae, dorsal margin with one pair of setae and ventral margin with 2 setae in row; flagellum articles 5-6 with final article cone-shaped; all articles with one pairs of tooth setae on disto-dorsal margin; last article with a group of simple setae on apex. Antenna 2 long 1/4 of body size; peduncular articles narrow; peduncular article 5 approximately 1.5 times as long as article 4; peduncle article 3 with bifid setae on all distal margin; peduncle article 4 with sparse 
bifid setae on all margin; peduncle article 5 ventral margin with 6 groups of bifid setae in row, on dorsal margin 5 groups of bifid setae in row ( 2 or 3 setae for group); flagellum sub-equal than peduncles, 21 -articulated final article is cone-shaped; all article with 4 tooth setae around distal margin; last article with much simple setae on apex. Upper lip (labrum) entire, apical margin with tooth setae. Lower lip (labium) with wide lobes and shoulders apically abundance tooth setae. Mandible stout, incisor 5-dentate (last is bi-dentate), left lacinia 4-dentate, molar finely serrated (Figure 9). Maxilla 1 inner plate narrow with oblique apex and 2 stout apical robust plumose setae; outer plate with 8 tooth setae, medially serrate tooth setae; palp slender 1-articulate. Maxilla 2 inner plate with 1 stout long, plumose seta medially and robust setae distally; outer plate rounded distally armed with tooth setae. Maxilliped inner plates with plumose setae on apical margin with 3 robust setae (tri-dentate); outer plate slightly shorter than basal height in length, with tooth setae apically; palp article 3 rounded apically and densely covered with tooth setae, article 4 absent. On external margin bifid setae are present (see Figure 5).

Peraeon. Peraeonite 1-5 subequal in length. Gnathopod 1 coxa anterior margin straight and anterior distally sub-acute, with marginal setae; basis slightly expanded posterodistally with a row of 7 setae on anterior margin and a row of 4 setae on posterior margin; ischium shortest, rounded posteriorly, with 2 groups of setae on posterior margin and with a process on anterior margin; merus with a row of 4 groups of setae on posterior margin; merus and carpus connected by diagonal joint; carpus approximately 1.5 times as long as propodus, slightly curved posteriorly with lobe postero-distally equipped with row of setae and with a row of 3 group of setae on anterior margin; propodus expanded distally with a row of setae and a row of 5 group of setae (4 groups of setae in smallest specimens) on anterior margin, palmar margin (with setae) longer than dactylus; dactylus narrow with a group of setae on inner margin, subchelate. Gnathopod 2 coxa slightly wider than deep, with marginal setae and with postero-proximal process and postero-distal process ('cusp' sensu Bousfield \& Hendrycks 2002); basis subrectangular with a row of setae on anterior and posterior margin; ischium narrow with dorsal process; merus little sub-rectangular; carpus distinct; propodus elongate ovoid, slight protuberance near dactylar hinge, palmar margin equipped with row of setae; dactylus curved distally with proximal protuberance and near hinge with a depression; sub-chelate (see Variation par. below for other details). Peraeopod 3-4 coxa sub-quadrate, with marginal setae and with pointed process posterior marginal (cusp); all anterior and posterior margin of peraeopods have group of setae; basis with straight anterior and weakly convex posterior margin; ischium the shortest with posterior marginal notch; merus slightly expanded; carpus approximately 0.7 times as long as merus; propodus slender, slightly longer than carpus; dactylus slender with single setae on inner margin. Peraeopod 5 coxa bi-lobed, anterior lobe wider and slightly longer than posterior one, both with marginal setae; all anterior and posterior margin of peraeopods have group of setae; basis lobed; ischium wider than long with posterior marginal notch; merus as wide as ischium, slightly produced postero-distally; carpus sub-equal to merus in length; propodus narrow, sub-equal to carpus in length; dactylus with single seta enter-marginally. Peraeopod 6 much longer than preceding peraeopods; coxa bilobed, anterior lobe much shorter and narrow than posterior lobe, with marginal setae; all anterior and posterior margin of peraeopod have group of setae; basis rounded, posterior margin moderately expanded; ischium with posterior marginal notch; merus slightly expanded distally; carpus sub-rectangular, sub-equal in length and narrower to merus; propodus very narrow, approximately 1.3 times of merus length, dactylus narrow with seta anterior marginal. Peraeopod 7 longer than peraeopod 6; coxa rounded posteriorly, marginal setae; all anterior and posterior margin of peraeopod have group of setae; basis rounded, posterior margin expanded; ischium with posterior marginal process; merus slightly expanded distally; carpus sub-rectangular, longer and narrower than merus; propodus very narrow, dactylus narrow with seta anterior marginal.

Pleon. Pleopods well developed; peduncles not expanded; bi-ramous, rami shorter than peduncle with more long plumose setae. Epimeron 2 sub-equal in length to epimeron 3. Epimeron 3 posterior margin smooth, posteroventral corner. Uropod 1 peduncle sub-equal than rami, with 4-5 (5-7) robust setae along lateral margin, distolateral peduncular spine-like seta; outer ramus slightly shorter than inner ramus, marginally with 2-3 marginal robust setae; inner ramus with 3-5 marginal robust setae; both rami with rounded apex with group of long stout distal robust setae. Uropod 2 peduncle sub-equal to rami, with setae along lateral margin; inner ramus sub-equal in length to outer ramus; inner ramous with 4-5 marginal robust setae; outer ramus with 1-2 marginal robust setae. Uropod 3 uniramous; peduncle stout, with 4-5 medial and distal robust setae; ramus shorter than peduncle, linear, with 1-4 marginal and 4-7 apical setae. Telson fleshly, with the 2 lobes fused on base; longer than broad, weakly cleft, with lateral and distal bifid setae. 

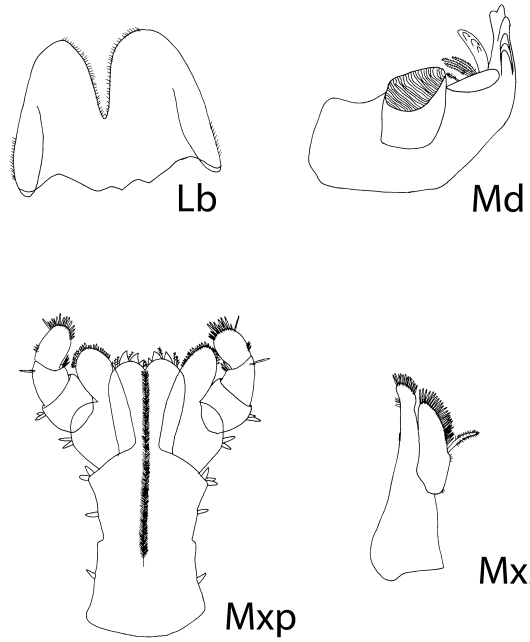

$M \times 2$

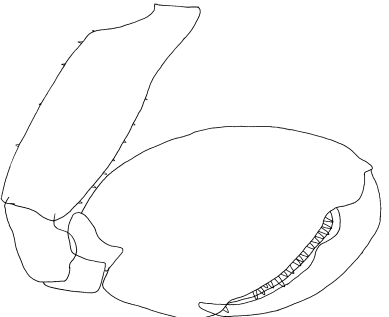

Gn2 morphotype IV
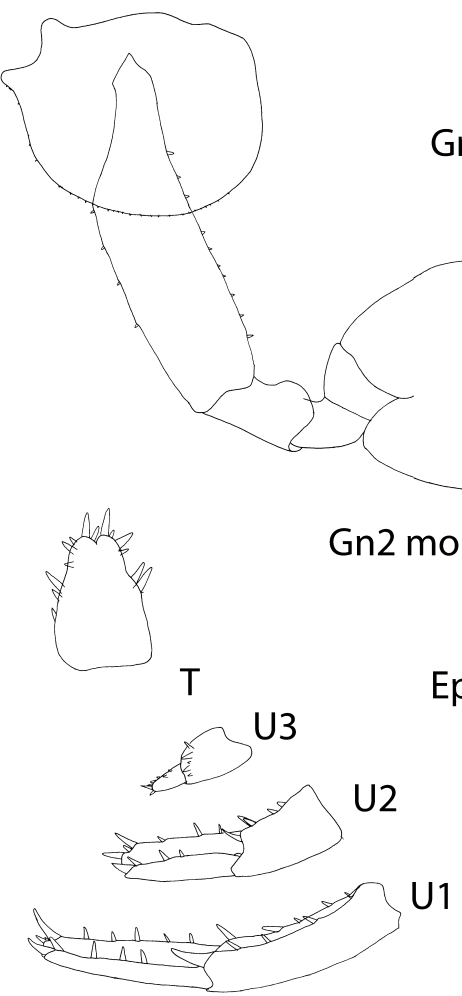
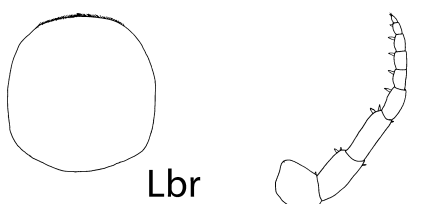

A1
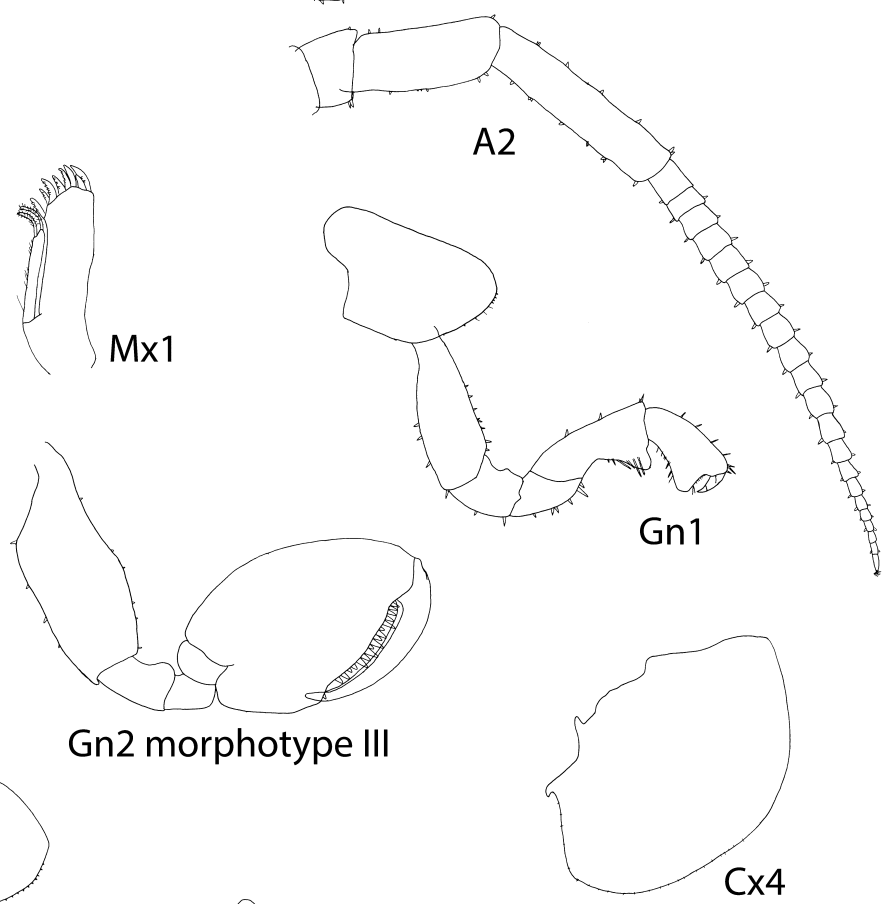

Gn2 morphotype III

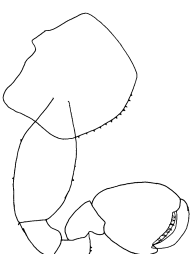

Gn2 morphotype I

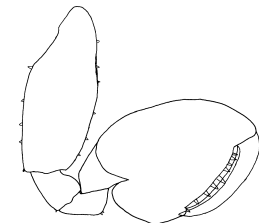

Gn2 morphotype II

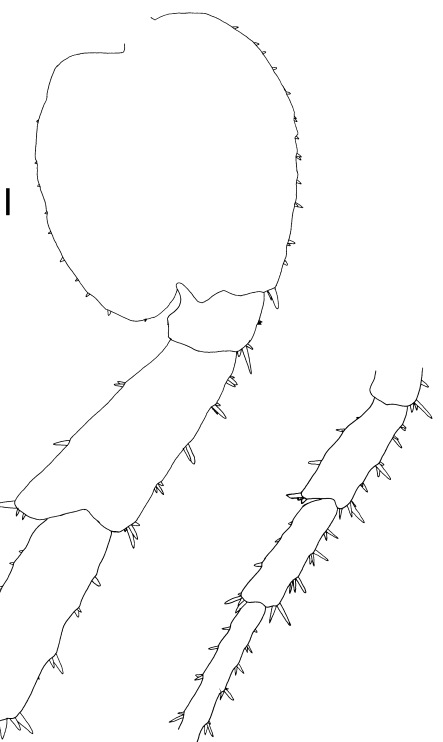

P7 morphotype I

PI
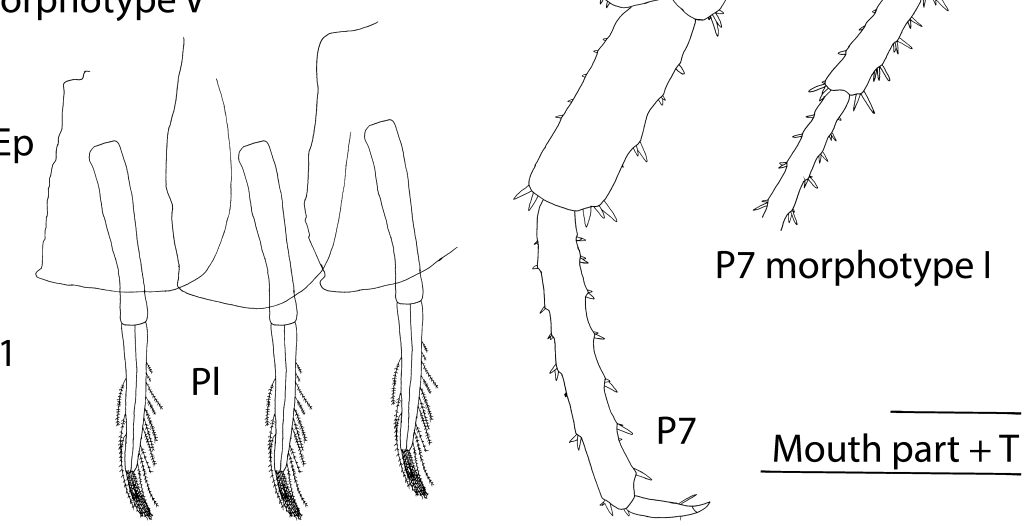

FIGURE 7. Iconography of Orchestia stephenseni Cecchini, 1928. Male. Morphotype V. Gnathopods 2 of specimens ascribed to Morphotype I-IV are shown. Peraeopod 7 of specimens ascribed to Morphotype I is shown. See text for terminology. Scale bar $=1 \mathrm{~mm}$. 

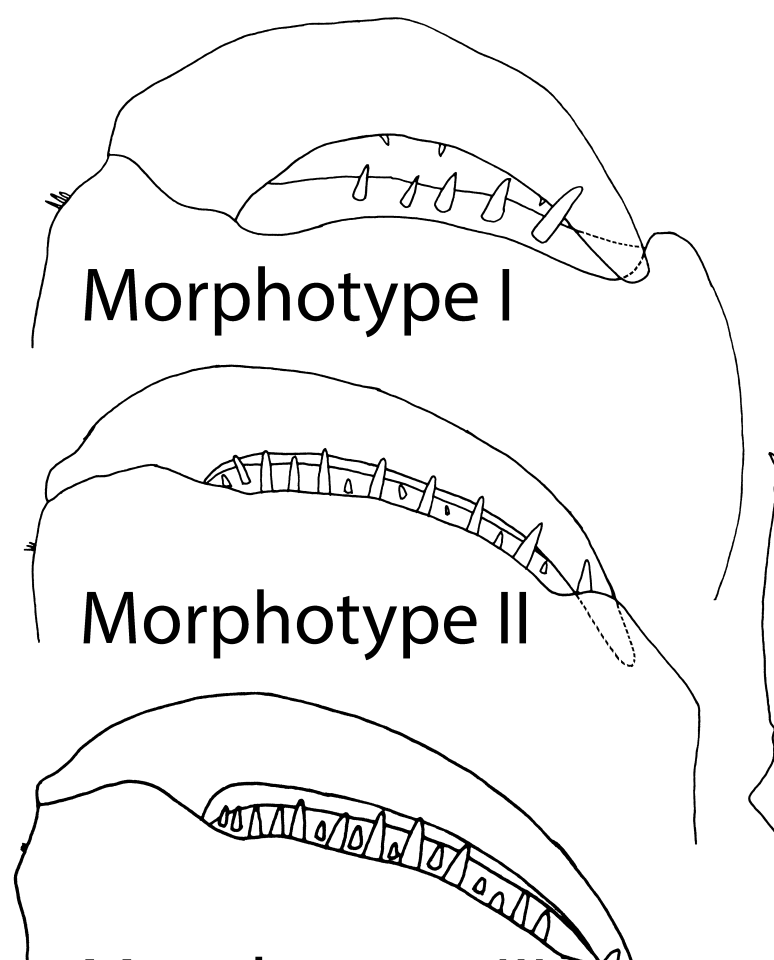

Morphotype III
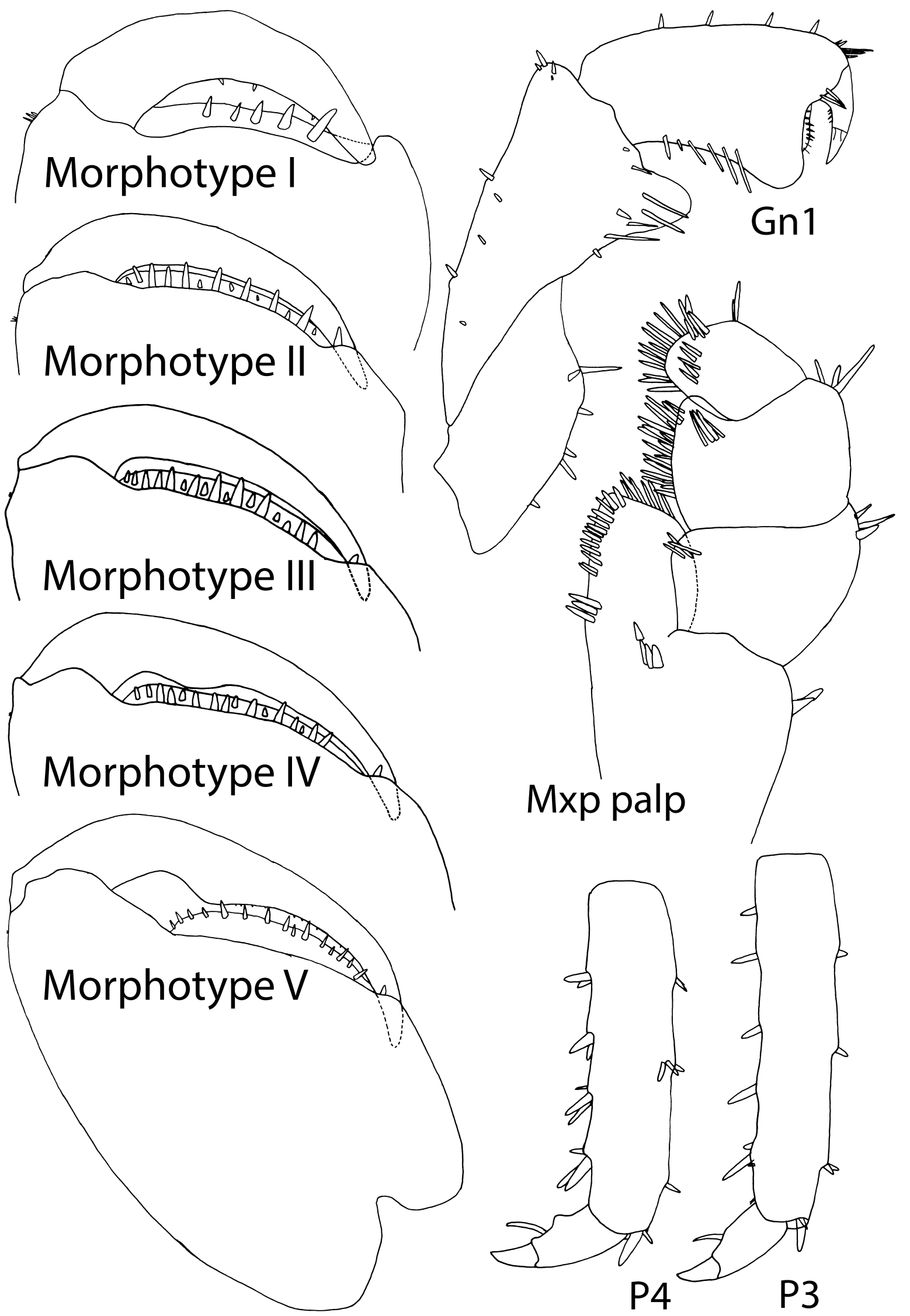

FIGURE 8. Orchestia stephenseni Cecchini, 1928. Male. Details of shapes of palm and dactylus of gnathopod 2, dactylus of peraeopod 3 and peraeopod 4, merus, carpus and propodus of gnathopod 1 and palp of maxilliped. 


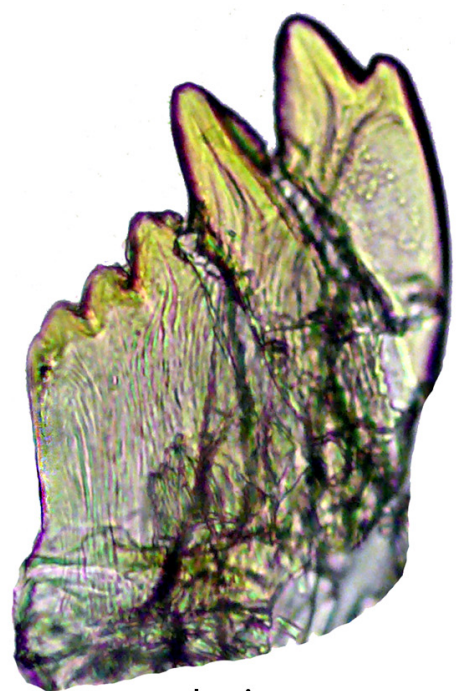

Incisor

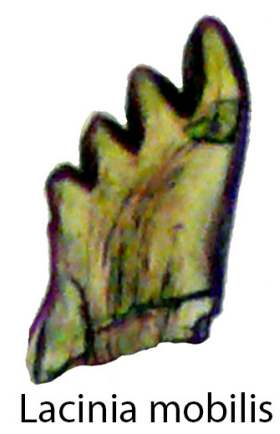

FIGURE 9. Orchestia stephenseni Cecchini, 1928. Male. Incisor and lacinia mobilis.

Variation. Morphotype I: Gnathopod 2 propodus trapezoid; palm slightly convex, extending about $40 \%$ of posterior margin with a distal small protuberance, where tip of dactylus closes; dactylus smoothly arcuate. Morphotype II: Gnathopod 2 propodus sub-ovate; palm slightly convex, extending about $70 \%$ of posterior margin with a distal very small protuberance, where tip of dactylus closes; dactylus slender distally. Morphotype III: Gnathopod 2 propodus ovate; dactylus slender distally, as long as the palm of propodus. Morphotype IV: Gnathopod 2 propodus ovate; dactylus posterior margin with postero-proximal sinus and protuberance. Morphotype V: Gnathopod 2 propodus ovate; palm with postero-proximal sinus; dactylus posterior margin with well-developed postero-proximal sinus and protuberance.

Remarks. The material, originally described by Cecchini (1928), was collected from La Spezia (northern Italy). However, a holotype was never designated (Lowry \& Fanini 2013); thus, a neotype has been designated from the collection in Sicily (southern Italy).

\section{Discussion}

Molecular analysis. Over the past decade, DNA Barcoding has played a facilitator role in the accurate identification of marine fauna, thanks to the integration of molecular and traditional taxonomic methods (Costa et al. 2007; Landi et al. 2014). Molecular analysis has defined the three syntopic species in three monospecific clades, correlating with $O$. stephenseni, O. montagui and $O$. mediterranea respectively and, at the same time, this type of analysis has clustered the five morphotypes detected in $O$. stephenseni. It has also revealed a low divergence among specimens of $O$. stephenseni analysed, which can be described as natural intraspecific variability (Figure 6). The identification of $O$. stephenseni morphotypes was verified by the neotype mitochondrial DNA sequence, against which the reference library containing the DNA barcodes could be matched. 


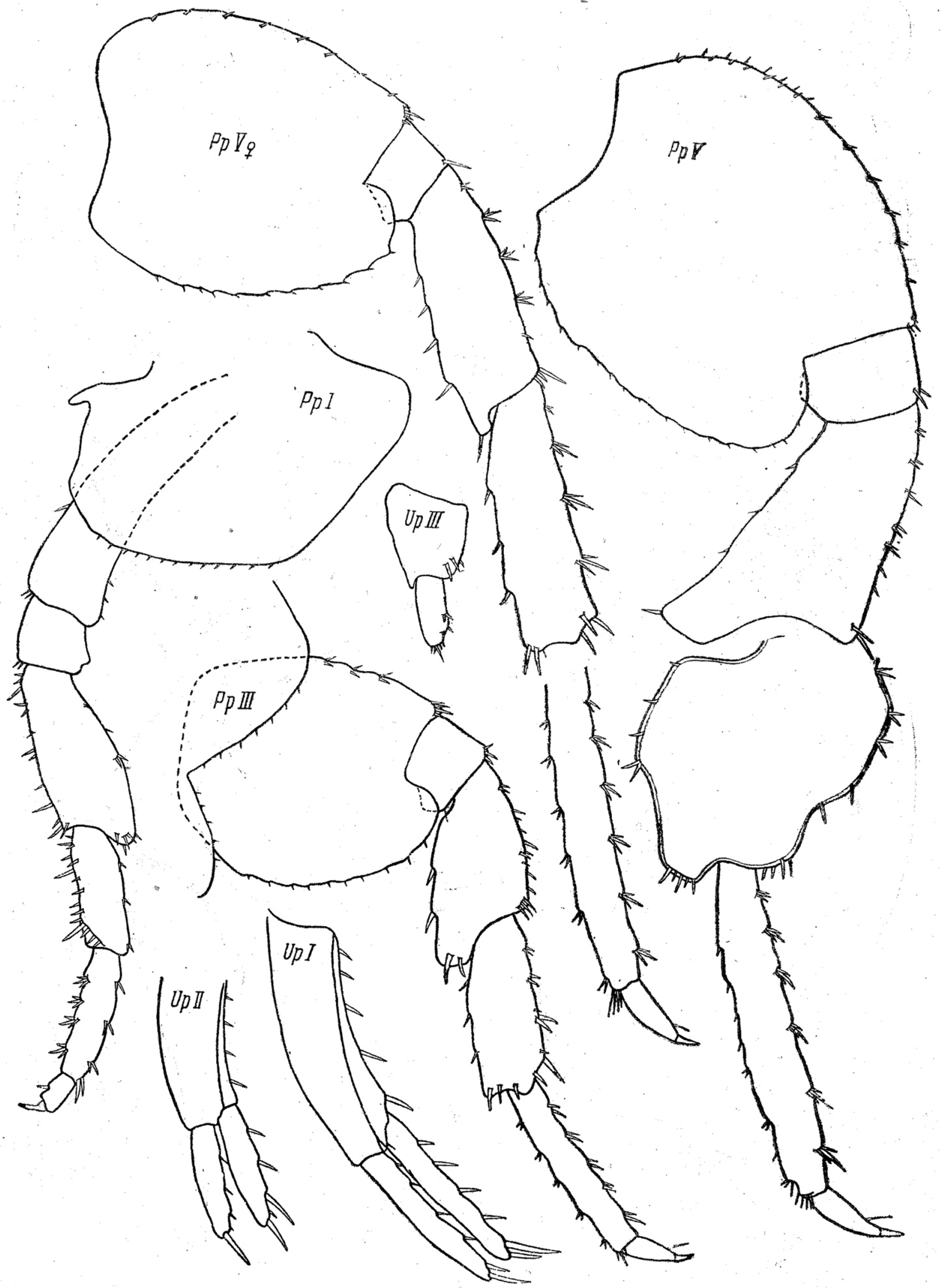

Puc. 556. Orchestia mediterranea Costa.

FIGURE 10. Iconography of Orchestia mediterranea A. Costa, male, by Bulycheva (1957); PpV, peraeopod 7. 
The NJ tree (Figure 6) showed a robust monophyly for the four Orchestia species under analysis; the branch lengths, and consequently the genetic distances, are deep enough to delimit the four species included in the tree. Few authors have performed COI sequences on talitrid species. Such data report genetic distances among Talitridae species ranging from 0.2 to $41.0 \%$, and values between pairs of Orchestia species ranging from 1.0 to $31.0 \%$ (Wildish et al. 2012, and references therein), thus highlighting wide-ranging values for the whole family.

The wide inter-species COI distance is not uncommon in amphipods. Within Caprellidae, Pilar Cabezas et al. (2013) scored an inter-species divergence ranging from 7.6 to $15.4 \%$; or within Iphimediidae and Epimeriidae, Lörz et al. (2009) scored an inter-species divergence ranging respectively from 7.9 to $29.5 \%$ and from $8.5 \%$ to $26.2 \%$.

As talitrids occur in different environments and they are cosmopolitan, the talitrid species can have an intraspecies gene pool strongly influenced by selective pressures or by high gene flow (Pavesi \& Ketmaier 2013; Pavesi et al. 2013); consequently various species cannot be easily discriminated by molecular techniques due to cases of homoplasy. However, here DNA Barcoding has confirmed the co-specificity of morphological variation of specimens, and it has been demonstrated as an equivalent to morphological taxonomy for species diagnosis. The clades grouping the intra-species haplotypes are well separated and the inter-species distance values do not overlap intra-species divergence values.

Morphotype variation. Talitrids attain the largest body-size of all the intertidal amphipods in the Mediterranean Sea, up to a maximum length of $21 \mathrm{~mm}$ (those reported in this paper), and the morphological characters of individuals markedly change throughout their growth period. The specimens of $O$. stephenseni studied in Sicily ranged from 11 to $21 \mathrm{~mm}$ in length and, although they have been discriminated into five different morphotypes (I to V), definite stages of maturity have not yet been discriminated. The current classification of the Mediterranean Orchestia genus is based primarily on male, sexually dimorphic characters including: the shape of peraeopod 7 merus and carpus, and the shape of gnathopod 2 propodus and dactylus (Bellan-Santini 1993; Lowry \& Fanini, 2013). These sexually dimorphic characters, which have been observed in this study, here are variable throughout their growth period (Figure 2).

Orchestia stephenseni is the only Mediterranean species within the Orchestia genus with a peraeopod 7 merus and carpus which is never dilated (Bellan-Santini 1993), and the oval shaped propodus with a relatively long dactylus and short median tooth in gnathopod 2, here corresponding to Morphotypes I to IV. These characters (peraeopod 7 and gnathopod 2) are shared with various growth stages of other Orchestia species, and they have been the cause of misidentification or uncertain identification in the past. The Morphotypes III, IV and V can be misidentified with other co-generic species e.g. gnathopod 2 Morphotype $\mathrm{V}$ is similar to the gnathopod 2 of $O$. montagui, and gnathopod 2 Morphotype III and IV is similar to the gnathopod 2 of $O$. mediterranea.

The history of the name $O$. stephenseni is overflowing with erroneous identifications and uncertainties but, in some cases, clarified by this revised description. Bulycheva (1957) has proposed the synonymy of $O$. stephenseni Cecchini, 1928 with $O$. mediterranea A. Costa, 1853, and this idea was taken up by Barnard (1958) in his checklist. The description of $O$. mediterranea A. Costa 1853 was revised by Bulycheva (1957) and it has since been listed in subsequent synonymy of $O$. stephenseni Cecchini, 1928 by Bellan-Santini (1993) and Lowry \& Fanini (2013). However, the illustration of pereaopod 7 (Bulycheva, 1957; Figure 10) shows an expanded peraeopod 7 merus and carpus which is more likely attributable to $O$. mediterranea. Based on this iconography, the synonymy proposed by Bulycheva 1957 is rejected.

The first description of $O$. stephenseni by Cecchini (1928) contained limited information regarding its features: it only described the male gnathopod 2 and discussed the similarity with the gnathopod 2 of $O$. mediterranea A. Costa, 1853, which perpetuated further confusion. The $O$. ghigii species described by Vecchi (1929) was previously described as a junior synonym of $O$. stephenseni by Ruffo (1949). This placement of $O$. ghigii can be supported by this study, based on the assessment of morphology discussed in this paper, as compared to the description by Vecchi (1929). Lowry \& Fanini (2013) queried the placement of several works as part of the synonymy of $O$. stephenseni, including $(i)$ the $O$. stephenseni recorded by Calvario \& Marques (1983) in the Atlantic Ocean; (ii) the record of $O$. montagui by Carus (1885); and (iii) $O$. constricta described by A. Costa, 1853, which can be resolved by the dataset outlined in this paper.

Orchestia stephenseni in Calvario \& Marques (1983) is here considered a misidentification. Their illustration lacks the peduncular spine-like seta in uropod 1 , which is now considered an important character for identifying $O$. stephenseni. As the record of this species by Calvario \& Marques (1983) is the only one from the Atlantic Ocean, $O$. stephenseni is here confirmed to be a Mediterranean endemic species. 
The report of Orchestia montagui in Carus (1885) is here considered as a valid identification and removed from the synonymy of $O$. stephenseni: Carus described the peraeopod 7 merus and carpus expanded, a characteristic of $O$. montagui ("pedes posteriors majors, articuli 4. et 5. in 3 adultis plerumque dilatati, 4. retro in apicem productus", Carus 1885).

Orchestia constricta A. Costa, 1853 matched the O. stephenseni Morphotype V defined here; the author described the $O$. constricta species with a peraeopod 7 merus and carpus which was never dilated and the particular shape of gnathopod 2 corresponding to Morphotype V. Heller (1866) collected O. constricta in the Adriatic basin, within the Mediterranean, and described a gnathopod 2 like Morphotype $\mathrm{V}$, separating it from O. montagui, which had also been collected in the same area. Thus, $O$. constricta A. Costa, 1853 can be considered as a senior synonym of $O$. stephenseni, although $O$. constricta has already been proposed as species dubia by Karaman (1973).

The name $O$. constricta A. Costa, 1853 occurs prior to O. stephenseni Cecchini, 1928, and, in accordance with the Principle of Priority, the name to be accepted by the academic community should be $O$. constricta. However, a Reversal of Precedence in Zoological Nomenclature (ICZN http://iczn.org/) establishes that the Principle of Priority cannot be followed and that the prevailing usage must be maintained when the following conditions are both met: "the senior synonym or homonym has not been used as a valid name after 1899, (art. 23.9.1.1.) and the junior synonym or homonym has been used for a particular taxon, as its presumed valid name, in at least 25 works, published by at least 10 authors in the immediately preceding 50 years and encompassing a span of not less than 10 years (art. 23.9.1.2.)". In this case the name Orchestia stephenseni matches the art. 23.9.1., and is here recommended.

Statement of the Reversal of Precedence. The Principle of Priority (Article 23 of the International Code of Zoological Nomenclature, ICZN 2000) would require the older name to be used (i.e., Orchestia constricta A. Costa, 1853). In this case, the direct application of the Principal of Priority is not in the interests of nomenclatural stability because the younger name (i.e. Orchestia stephenseni Cecchini, 1928) is in current and widespread usage (see the references in Appendix 1). Indeed, the ICZN 2000 establishes that the Principle of Priority cannot be followed and prevailing usage must be maintained when the following conditions are both met:

Orchestia stephenseni takes precedence over the objective synonym Orchestia constricta, in accordance with article 23.9.1. of the ICZN.

Orchestia constricta A. Costa, 1853, the senior synonym or homonym, has not been used as a valid name after 1899, (art. 23.9.1.1.): since 1899, the name Orchestia constricta A. Costa, 1853 has been mentioned once (e.g. Stebbing, 1906), thereby filling Article 23.9.1.1 of the Code.

Orchestia stephenseni Cecchini, 1928, the junior synonym or homonym has been used for a particular taxon, as its presumed valid name, in at least 25 works, published by at least 10 authors in the immediately preceding 50 years and encompassing a span of not less than 10 years (art. 23.9.1.2.):

Appendix 1 demonstrates that the name Orchestia stephenseni matches the second condition. In the past 65 years (since 1951), at least 30 publications by 64 different authors have used Orchestia stephenseni as a valid species name, thereby fulfilling Article 23.9.1.2 of the Code.

As both requirements of Article 23.9.1 of the Code have been met, Orchestia stephenseni Cecchini, 1928 takes precedence over the objective synonym Orchestia constricta A. Costa, 1853, in accordance with Article 23.9.2. Orchestia stephenseni Cecchini, 1928 becomes a nomen protectum, and Orchestia constricta A. Costa, 1853 a nomen oblitum.

\section{References}

Akbulut, M., Ustaoğlu, M.R. \& Çelik, E.Ş. (2009) Freshwater and brackish water Malacostraca (Crustacea-Arthropoda) fauna of Sinop and Samsun and their ecology. Journal of the Black Sea/Mediterranean Environment, 15 (1), 47-60.

Audouin, V. (1826) Explication sommaire des planches de crustaces de l'Egypte et de la Syrie, publiees par Jules-Cesar Savigny, membre de l'Institut; offrant un expose des caracteres naturels des genres, avec la distinction des especes. Description de l'Egypte, Histoire Naturelle, 1, 77-98.

Ariani, A.P., Camassa, M.M. \& Wittmann, K.J. (2000) The dolinas of Torre Castiglione (Gulf of Tarent, Italy): environmental and faunistic aspects of a semi-hypogean water system. Mémoires de Biospeléologie, 27, 1-14. 
Barnard, J.L. (1958) Index to the families, genera, and species of the gammaridean Amphipoda (Crustacea). Allan Hancock Foundation publications, Occasional paper, 19, 1-145.

Bellan-Santini, D. (1993) Family Talitridae. In: Ruffo, S. (Ed.), The Amphipoda of the Mediterranean, Part 3, Gammaridea (Melphidippidae to Talitridae) Ingolfiellidea, Caprellidea. Mémoires de l'Institute Océanographique, Monaco, 13, 728760.

Bousfield, E.L. (1982) The amphipod superfamily Talitroidea in the northeastern Pacific region. Family Talitridae. Systematics and distributional ecology. National. Museum of Natural Science, Publications in Biological Oceanography, 11, i-vii, 173.

Bousfield, E.L. \& Hendrycks, E.A. (2002) The talitroidean amphipod family Hyalidae revised, with emphasis on the North Pacific fauna: systematics and distributional ecology. Amphipacifica, 3 (3), 17-134.

Bulycheva, A.I. (1957) Sea fleas of the seas of the USSR and adjacent waters (Amphipoda-Talitroidea) Opredeliteli po faune SSSR, 65, 1-185. [in Russian]

Calvario, J. \& Marques, J.C. (1983) Étude systématique et écologique d'une collection d'Amphipodes de la zone intertidale de l'estuaire du Tage (Portugal). Occurrence d'Orchestia kosswigi Ruffo, 1949 et d'Orchestia stephenseni Cecchini, 1928. Ciência biológica, ecology and systematics, 5 (1), 79-95.

Carus, J.V. (1885) Prodromus faunae Mediterranee sive Descriptio Animalium maris Mediterranei incolarum quam comparata silvarerum quatenusin notuitadiectis locis et nominibus vulgaribus eorumque auctoribus in commodum Zoologorum Zoologorum. Vol. 1. Coelenterata, Echinodermata, Vermes, Arthropoda. - Stuttgart,: E. Schweizerbart sche Verlagshandlung, 11, 399. http://dx.doi.org/10.5962/bhl.title. 11523

Cecchini, C. (1928) Contributo alla conoscenze degli anfipodi. Memoria Reale Comitato Talassografico Italiano, 142, 1-10.

Cecchini, C. (1929) Gli Anfipodi del R. Museo Zoologico di Firenze. Fam. Talitridae. Atti della R. Accademia Fisiocritici in Siena, Series 10, 3 (5-7), 3-16 (767-780).

Chevreux, E. (1911) Campagnes de la Melita. Les Amphipodes d'Algérie et de Tunisie. Mémoires de La Société zoologique de France, 23 (3-4), 145-285.

Colombini, I., Chelazzi, L. \& Fallaci, M. (2002) Community structure of terrestrial invertebrates inhabiting a tidal marsh islet in the Mediterranean Sea (Gulf of Gabes, Tunisia). The Scientific World Journal, 2, 861-868.

Costa, A. (1853) Relazione sulla memoria del Dottor Achille Costa, di ricerche su Crostacei Anfipodi del Regno di Napoli. Rendiconto della Società reale Borbonica, Accademia delle scienze, (N.S.) 2, 181-183. http://dx.doi.org/10.5962/bhl.title.2070

Costa, A. (1857) Ricerche sui crostacei anfipodi del regno di Napoli. Memorie della Reale Accademia delle Scienze di Napoli, $1,181-183$. http://dx.doi.org/10.5962/bhl.title.2070

Costa, F.O., DeWaard, J.R., Boutillier, J., Ratnasingham, S., Dooh, R.T., Hajibabaei, M. \& Hebert, P.D. (2007) Biological identifications through DNA barcodes: the case of the Crustacea. Canadian Journal of Fisheries and Aquatic Sciences, 64 (2), 272-295.

Dana, J.D. (1853) Crustacea, Part II United States Exploring Expedition during the years 1838, 1839, 1840, 1841, 1842, under the command of Charles Wilkes, U.S.N., 14, 686-1618. http://dx.doi.org/10.5962/bhl.title.63979

Davolos, D., Ketmaier, V., Cobolli, M. \& De Matthaeis, E. (2002) Struttura genetica e livelli di differenziamento tra popolazioni e specie di Orchestia (Amphipoda, Talitridae) del Mediterraneo. Biogeographia, 23, 23-34.

Davolos, D., Iannilli, V., De Matthaeis, E. \& Pietrangeli, B. (2005) Molecular phylogenetic analysis in ecogenotoxicological studies. Prevention Today, 1 (3-4), 69-77.

Deidun, A., Saliba, S. \& Schembri, P.J. (2007) Banquette faunal assemblages from groomed and ungroomed beaches on the Maltese Islands. Rapport Commission International pour l'exploration scientifique de la Mer Mediterranee, Monaco, 38, 456.

Deidun, A. \& Schembri, P.J. (2008) Long or short? Investigating the effect of beach length and other environmental parameters on macrofaunal assemblages of Maltese pocket beaches. Estuarine, Coastal and Shelf Science, 79, 17-23. http://dx.doi.org/10.1016/j.ecss.2008.03.001

Deidun, A., Saliba, S. \& Schembri, P.J. (2009) Considerations on the ecological role of wrack accumulations on sandy beaches in the Maltese Islands and recommendations for their conservation management. Journal of Coastal Research, SI 56, 410414.

De Matthaeis, E., Ketmaier, V., Davolos, D. \& Cobolli, M. (1999) Strutturazione genetica e pattern di flusso genico in quattro specie de Anfipodi Talitridi sopralitorali dell'area egea. Biogeographia, 20, 95-104.

De Matthaeis, E., Davolos, D., Cobolli, M. \& Ketmaier, V. (2000) Isolation by distance in equilibrium and nonequilibrium populations of four talitrid species in the Mediterranean Sea. Evolution, 54 (5), 1606-1613. http://dx.doi.org/10.1554/0014-3820(2000)054[1606:IBDIEA]2.0.CO;2

Fanini, L., Cantarino, C.M. \& Scapini, F. (2005) Relationships between the dynamics of two Talitrus saltator populations and the impacts of activities linked to tourism. Oceanologia, 47 (1).

Ferraris, Jr C.J. \& Eschmeyer, W.N. (2000) International Code of Zoological Nomenclature. Copeia, 3, 907-908. http://dx.doi.org/10.1643/0045-8511(2000)000[0907:BR]2.0.CO;2

Fišer, C. (2002) Prispevek k poznavanju postranic iz skkupine Gammaridea (Amphipoda, Gammaridea) slovenske morske 
obale [A contribution to the knowledge of amphipods of the groups Gammaridea (Amphipoda, Gammaridea) on the Slovene coast]. Natura Sloveniae, 4 (1), 33-39.

Fish, S. (1972) The setae of Eurydice pulchra (Crustacea: Isopoda). Journal of Zoology London, 166, $163-177$. http://dx.doi.org/10.1111/j.1469-7998.1972.tb04083.x

Folmer, O., Black, M., Hoeh, W., Lutz. R. \& Vrijenhoek, R. (1994) DNA primers for amplification of mitochondrial cytochrome c oxidase subunit I from diverse metazoan invertebrates. Molecular Marine Biology and Biotechnology 3, 294-299.

Grintsov, V.A. (2011) Morfologicheskie razlichiya samok rodov Orchestia i Platorchestia (Amphipoda, Talitridae) supralitorali Chernogo Morya (krym) [Morphological differences between females of Orchestia and Platorchestia (Amphipoda, Talitridae) supralittoral Black Sea (Crimea)]. Zoologicheskii Zhurnal, 90 (2), 143-148.

Heller, C. (1866) Beiträge zur naheren Kenntniss der Amphipoden des Adriatischen Meeres. Denkschriften der Kaiserlichen Akademie der Wissenschaften, Mathematisch-naturwissenschaftliche Klasse, 26, 1-62, pls 1-4. http://dx.doi.org/10.5962/bhl.title.6483

Henzler, Christine, M. \& Ingólfsson, A. (2007) The biogeography of the beachflea, Orchestia gammarellus (Crustacea, Amphipoda, Talitridae), in the North Atlantic with special reference to Iceland: a morphometric and genetic study. Zoologica Scripta, 37 (1), 57-70. http://dx.doi.org/10.5962/bhl.title.6483

Jelassi, R., Khemaissia, H. \& Nasri?Ammar, K. (2012) Intra?annual variation of the spatiotemporal distribution and abundance of Talitridae and Oniscidea (Crustacea, Peracarida) at Bizerte Lagoon (northern Tunisia). African Journal of Ecology, 50 (4), 381-392. http://dx.doi.org/10.1111/j.1365-2028.2012.01326.x

Jelassi, R. \& Nasri-Ammar, K. (2012) Temporal variation in the shore amphipod community in the supralittoral zone of Bizerte Lagoon (northern Tunisia). Crustaceana, 85 (4-5), 433-446 http://dx.doi.org/10.1163/156854012X636706

Karaman, G.S. (1970) XXIX. Beitrag zur Kenntnis der Amphipoden. Genus Orchestia (Talitridae) in adriatischem Meer. Glasnik Republickog zavoda za zastitu prirode i prirodnjacke muzeja u Titogradu, 3, 5-36, 8 pls.

Karaman, G.S. (1973) XLV. Contribution to the knowledge of the Amphipoda. Orchestia stephenseni Cecchini 1928, one new species for Adriatic fauna (Gammaridea: Talitridae). Fragmenta Balcanica, Musei Macedonici Scientiarum Naturalium, Skopje, 9 (14/214), 137-145.

Kimura, M. (1980) A simple method for estimating evolutionary rate of base substitutions through comparative studies of nucleotide sequences. Journal of Molecular Evolution 16, 111-120. http://dx.doi.org/10.1007/BF01731581

Koukouras, A. \& Russo, A. (1991) Midlittoral Soft Substratum Macrofaunal Assemblages in the North Aegean Sea. Marine Ecology, 12 (4), 293-316. http://dx.doi.org/10.1111/j.1439-0485.1991.tb00260.x

Landi, M., Dimech, M., Arculeo, M., Biondo, G., Martins, R., Carneiro, M., Carvalho, GR., Lo Brutto, S. \& Costa, F.O. (2014) DNA Barcoding for Species Assignment: The Case of Mediterranean Marine Fishes. PLoS ONE 9 (9), e106135. http://dx.doi.org/10.1371/journal.pone.0106135

Leach, W.E. (1814) Article Crustaceology. In The Edinburgh encyclopaedia, 7, 429-437.

Lo Brutto, S., Arculeo, M., Krapp-Schickel, T. \& Ketmaier, V. (2013) Foreword to the Special Issue "New frontiers for monitoring European biodiversity: the role and importance of amphipod crustaceans". Crustaceana, 86 (7-8), 769-779. http://dx.doi.org/10.1163/15685403-00003204

Lowry, J.K. \& Fanini, L. (2013) Substrate dependent talitrid amphipods from fragmented beaches on the north coast of Crete (Crustacea, Amphipoda, Talitridae), including a redefinition of the genus Orchestia and descriptions of Orchestia xylino sp. nov. and Cryptorchestia gen. nov. Zootaxa, 3709 (3), 201-229. http://dx.doi.org/10.11646/zootaxa.3709.3.1

Lowry, J.K. \& Myers, A.A. (2013) A Phylogeny and Classification of the Senticaudata subord. nov. Crustacea: Amphipoda). Zootaxa, 3610 (1), 1-80. http://dx.doi.org/10.11646/zootaxa.3610.1.1

Lörz, A.N., Maas, E.W., Linse, K. \& Coleman, C.O. (2009) Do circum-Antarctic species exist in peracarid Amphipoda? A case study in the genus Epimeria Costa, 1851 (Crustacea, Peracarida, Epimeriidae). ZooKeys 18, 91-128. http://dx.doi.org/10.3897/zookeys.18.103

Lucena-Moya, P., Abraín, R., Pardo, I., Hermida, B. \& Domínguez, M. (2010) Invertebrate species list of coastal lagoons in the Balearic Islands. Transitional Waters Bulletin, 4 (1), 1-11.

Maccagno, T.P. (1939) Contributo alla conoscenza dei Crostacei della Tripolitania. Bollettino dei Musei di zoologia e di anatomia comparata della R. Universita di Torino, (3), 47 (103), 437-452.

Mateus, A. \& Mateus, E. de O. (1959) Note sur l'existence d'orchestia ghigii Vecchi B Banyuls-sur-Mer. Vie et milieu, 9, 4, 441-443.

Nair, K.K.C. \& Anger, K. (1979) Experimental studies on the life cycle of Jassa falcata (Crustacea, Amphipoda). Helgoländer wissenschaftliche Meeresuntersuchungen, 32 (4), 444-452.

http://dx.doi.org/10.1007/BF02277988 
Pallas, P.S. (1766) Miscellanea zoological. Quibus imprimis atque obscurae animalium species describuntur et observationibus iconibusque illustrantur. Hagea Comitum: P. Nav Cleef. xii-224 p.,14 pls.

Pavesi, L. \& Ketmaier, V. (2013) Patterns of genetic structuring and levels of differentiation in supralittoral talitrid amphipods: an overview. Crustaceana 86 (7-8), 890-907. http://dx.doi.org/10.1163/15685403-00003212

Pavesi, L., Deidun, A., De Matthaeis, E., Tiedemann, R. \& Ketmaier, V. (2012) Mitochondrial DNA and microsatellites reveal significant divergence in the beachflea Orchestia montagui (Talitridae: Amphipoda). Aquatic Sciences, 74 (3), $587-596$. http://dx.doi.org/10.1007/s00027-012-0250-y

Pavesi, L., Tiedemann, R., De Matthaeis, E. \& Ketmaier, V. (2013) Genetic connectivity between land and sea: the case of the beachflea Orchestia montagui (Crustacea, Amphipoda, Talitridae) in the Mediterranean Sea. Frontiers in Zoology, 10 (1), $1-19$. http://dx.doi.org/10.1186/1742-9994-10-21

Pérès, J.M. \& Picard, J. (1964) Nouveau manuel de bionomie benthique de la mer Méditerranée. Station Marine d'Endoume, 31 (47), 5-137.

Pilar Cabezas, M., Cabezas, P., Machordom, A. \& Guerra-García, J.M. (2013) Hidden diversity and cryptic speciation refute cosmopolitan distribution in Caprella penantis (Crustacea: Amphipoda: Caprellidae). Journal of Zoological Systematics and Evolutionary Research, 51, 85-99. http://dx.doi.org/10.1111/jzs.12010

Prato, E., Pastore, M. \& Pavia, B., (1995) Il popolamento ad anfipodi del sopralitorale del mar piccolo di Taranto. Thalassia Salentina, 21, 61-67.

Rasband, W.S. (2008) "ImageJ." Available from : http://rsbweb. nih. gov/ij/.

Rafinesque, C.S. [-Schmaltz] (1815) Analyse de la nature outableau de I'universitet des corps organises par C.S. Rafinesque. Palerme. http://dx.doi.org/10.5962/bhl.title.106607

Ruffo, S. (1937) Studi sui Crostacei Anfipodi. II. Nota su alcune specie del gen. Orchestia (Amphip. Talitridae). Bollettino della Società Entomologica Italiana, 69 (3), 35-40.

Ruffo, S. (1949) Hatayda tutulan yeni bir Talitrid'in teshisi. Étude sur les Crustacés Amphipodes. XX. Description d'un nouveau Talitride du Hatay (Orchestia Kosswigi n. sp.). Istanbul Üniversitesi fen Fakuiltesi mecmuasi, (B) 14 (4), 321326.

Ruffo, S. (1951) Studi sui Crostacei Anfipodi. XXV. Note sulle specie mediterranee del genere Orchestia (Amphip. Talitridae). Atti dell'Accademia di agricoltura, scienze e lettere di Verona, (6), 1 (= 1949-50), 1-9.

Ruffo, (Ed.) (1993) The Amphipoda of the Mediterranean. Part 3: Gammaridea (Melphidippidae to Talitridae), Ingolfiellidea, Caprellidea. Memoires de l'institut Oceanographique de Monaco, 13.

Ruffo, S. (1995) Amphipoda, in: Crustacea Malacostraca II. (Tanaidacea, Isopoda, Amphipoda, Euphausiacea). Checklist delle specie della Fauna Italiana, 30, 28-52.

Saitou, N. \& Nei, M. (1987) The neighbor-joining method: A new method for reconstructing phylogenetic trees. Molecular Biology and Evolution 4, 406-425.

Serejo, C.S. (2004) Cladistic revision of talitroidean amphipods (Crustacea, Gammaridea), with a proposal of a new classification. Zoologica Scripta, 33 (6), 551-586. http://dx.doi.org/10.1111/j.0300-3256.2004.00163.x

Sezgin, M., Kocataş, A. \& Katağan, T. (2001) Amphipod fauna of the Turkish central Black Sea region. Turkish Journal of Zoology, 25 (1), 57-61.

Sezgin, M. \& Aydemir Çil, E. (2010) Rocky bottom crustacean fauna of Sinop (Black Sea, Turkey) coast. Zoologica Baetica, $21,5-14$.

Stebbing, T.R.R. (1906) Amphipoda. I. Gammaridea. Das Tierreich, 21, xxxix-806.

Stefanidou, D. \& Voultsiadou-Koukoura, E. (1995) An account of our knowledge of the amphipod fauna of the Aegean Sea. Crustaceana, 68 (5), 597-615. http://dx.doi.org/10.1163/156854095X00845

Tamura, K., Stecher, G., Peterson, D., Filipski, A. \& Kumar, S. (2013) MEGA6: Molecular Evolutionary Genetics Analysis version 6.0. Molecular Biology and Evolution 30, 2725-2729. http://dx.doi.org/10.1093/molbev/mst197

Thomas, W.L. (1970) The setae of Austropotamobius pallipes (Crustacea: Astacidae). Journal of Zoology London, 160, 91142. http://dx.doi.org/10.1111/j.1469-7998.1970.tb02899.x

Thompson, J.D., Desmond, G.H. \& Toby, J.G. (1994) CLUSTAL W: improving the sensitivity of progressive multiple sequence alignment through sequence weighting, position-specific gap penalties and weight matrix choice. Nucleic acids research 22 (22), 4673-4680. http://dx.doi.org/10.1093/nar/22.22.4673

Ugolini, A., Ungherese, G., Somigli, S., Galanti, G., Baroni, D., Borghini, F. \& Focardi, S. (2008) The amphipod Talitrus saltator as a bioindicator of human trampling on sandy beaches. Marine Environmental Research, 65 (4), 349-357. http://dx.doi.org/10.1016/j.marenvres.2007.12.002 
Vecchi, A. (1929) [Ricerche faunistiche nelle isole italiane dell'Egeo.] Anfipodi. Archivio Zoologico Italiano, 13 (1-2), 249257.

Vecchi, A. (1931) Anfipodi di Cirenaica raccolti dal Prof. Edoardo Zavattari. Bolletino di Zoologia, 2 (1), 57-66. http://dx.doi.org/10.1080/11250003109434846

Watling, L. (1989) A classification system for crustacean setae based on the homology concept. Crustacean Issues, 6, 15-26.

Wildish, D.J., Pavesi, L. \& Ketmaier, V. (2012) Talitrid amphipods (Crustacea: Amphipoda: Talitridae) and the driftwood ecological niche: a morphological and molecular study. Journal of Natural History, 46 (43-44), 2677-2700. http://dx.doi.org/10.1080/00222933.2012.717971

Zakhama-Sraieb, R., Sghaier, Y.R. \& Charfi-Cheikhrouha, F. (2009) Amphipod biodiversity of the Tunisian coasts: update and distributional ecology. Marine Biodiversity Records, 2, e155. http://dx.doi.org/10.1017/s1755267209990820

Zavodnik, D. \& Kovačić, B.M. (2000) Index of marine fauna in Rijeka Bay (Adriatic Sea, Croatia). Natura Croatica, Croatian Natural History Museum, Zagreb, 9 (4), 255-379.

\section{APPENDIX 1}

The Principle of Priority is moderated by the Article 23.9.1 of the Code of Zoological Nomenclature that requires a Reversal of Precedence of a junior synonym when:

the senior synonym has not been used as a valid name after 1899 (Article 23.9.1.1);

and the junior synonym "has been used for a particular taxon, as its presumed valid name, in at least 25 works, published by at least 10 authors in the immediately preceding 50 years and encompassing a span of not less than 10 years" (Article 23.9.1.2).

The following list meets the condition Article 23.9.1.2:

30 selected publications, since 1951 treating the name Orchestia stephenseni as a valid species, published by 64 authors in the immediately preceding 50 years (thus, since 1965) and encompassing a span of not less than 10 years (in bold the names of the authors when are listed for the first time):

1 Ruffo, S. (1951) Studi sui Crostacei Anfipodi. XXV. Note sulle specie mediterranee del genere Orchestia (Amphip. Talitridae). Atti dell'Accademia di agricoltura, scienze e lettere di Verona, (6), 1(=1949-50), 1-9, 1 map.

2 Karaman, G.S. (1973) XLV. Contribution to the Knowledge of the Amphipoda. Orchestia stephenseni Cecchini, 1928, one new Species for Adriatic Fauna (Gammaridea: Talitridae). Fragmenta Balcanica, Musei Macedonici Scientiarum Naturalium, Skopje, 9 (14/214), 137-145.

3 Calvario, J. \& Marques, J.C. (1983) Étude systématique et écologique d'une collection d'Amphipodes de la zone intertidale de l'estuaire du Tage (Portugal). Occurrence d'Orchestia kosswigi Ruffo, 1949 et d'Orchestia stephenseni Cecchini, 1928. Ciência biológica, ecology and systematics, 5 (1), 79-95.

4 Koukouras, A. \& Russo, A. (1991) Midlittoral soft substratum macrofaunal assemblages in the North Aegean Sea. Marine Ecology, 12(4), 293-316.

DOI: $10.1111 / \mathrm{j} .1439-0485.1991 . t b 00260 . x$

http://onlinelibrary.wiley.com/doi/10.1111/j.1439-0485.1991.tb00260.x/abstract

5 Moreira, F., Assis, C. A., Almeida, P. R., Costa, J. L. \& Costa, M. J. (1992) Trophic relationships in the community of the upper Tagus estuary (Portugal): a preliminary approach. Estuarine, Coastal and Shelf Science, 34(6), 617-623. DOI:10.1016/S0272-7714(05)80066-http://www.sciencedirect.com/science/article/pii/S0272771405800666

6 Prato, E., Pastore, M. \& Pavia, B. (1995) Il popolamento ad anfipodi del sopralitorale del Mar Piccolo di Taranto. Thalassia Salentina, 21, 61-67.

DOI: $10.1285 / \mathrm{i} 15910725 \mathrm{v} 21 \mathrm{p} 61$

http://siba-ese.unisalento.it/index.php/thalassiasal/article/viewArticle/2475

7 Stefanidou, D. \& Voultsiadou-Koukoura, E. (1995) An account of our knowledge of the amphipod fauna of the Aegean Sea. Crustaceana, 68 (5), 597-615.

8 De Matthaeis, E., Davolos, D., Cobolli, M. \& Ketmaier, V. (2000) Isolation by distance in equilibrium and nonequilibrium populations of four talitrid species in the Marsala (western Sicily, southern Italy, central Mediterranean Sea. Evolution, 54(5), 1606-1613.

DOI: $10.1111 / \mathrm{j} .0014-3820.2000 . t b 00705 . x$

http://onlinelibrary.wiley.com/doi/10.1111/j.0014-3820.2000.tb00705.x/abstract

9 Ariani, A.P., Camassa, M.M. \& Wittmann, K.J. (2000) The dolinas of Torre Castiglione (Gulf of Tarent, Italy): environmental and faunistic aspects of a semi-hypogean water system. Mémoires de Biospeléologie, 27, 1-14. http://www.meduniwien.ac.at/user/karl.wittmann/docs/2000/Ariani_et_al_2000.pdf

10 Sezgin, M., Kocataş, A. \& Katağan, T. (2001) Amphipod fauna of the Turkish central Black Sea region. Turkish Journal of Zoology, 25(1), 57-61.

11 Gauci, M.J., Deidun, A. \& Schembri, P.J. (2005) Faunistic diversity of Maltese pocket sandy and shingle beaches: are 
these of conservation value?. Oceanologia, 47(2).

http://agro.icm.edu.pl/agro/element/bwmeta1.element.agro-article-1ecf4821-ca01-4560-b92b-073329d581e4

12 Davolos, D., Iannilli, V., De Matthaeis, E. \& Pietrangeli, B. (2005) Molecular phylogenetic analysis in ecogenotoxicological studies. Prevention Today, 1(3-4), 69-77.

http://preventiontoday.ispesl.it/pdf\%5Cric2005_03_5_en.pdf

13 Gönlügür-Demirci, G. (2006) Crustacea fauna of the Turkish Black Sea coasts: a check list. Crustaceana, 79(9), 11291139.

14 Silva, G., Costa, J.L., de Almeida, P.R. \& Costa, M.J. (2006) Structure and dynamics of a benthic invertebrate community in an intertidal area of the Tagus estuary, western Portugal: a six year data series. Hydrobiologia, 555(1), 115-128.*

DOI $10.1007 / \mathrm{s} 10750-005-1110-8$

http://link.springer.com/article/10.1007/s10750-005-1110-8

(*Silva et al (2006) report erroneously Orchestia stephenseni, as it is demonstrated herein to be a Mediterranean endemic species)

15 Sezgin, M. \& Katağan, T. (2007) An account of our knowledge of the amphipod fauna of the Black Sea. Crustaceana, 80(1), 1-11.

DOI: $10.1163 / 156854007779696479$

http://booksandjournals.brillonline.com/content/journals/10.1163/156854007779696479

16 Deidun, A., Saliba, S. \& Schembri, P.J. (2009) Considerations on the ecological role of wrack accumulations on sandy beaches in the Maltese Islands and recommendations for their conservation management. Journal of Coastal Research, SI $56,410-414$.

17 Akbulut, M., Ustaoğlu, M.R. \& Çelik, E.Ş. (2009) Freshwater and brackish water Malacostraca (Crustacea-Arthropoda) fauna of Sinop and Samsun and their ecology. Journal of the Black Sea/Mediterranean Environment, 15(1), 47-60.

18 Zakhama-Sraieb, R., Sghaier, Y.R. \& Charfi-Cheikhrouha, F. (2009) Amphipod biodiversity of the Tunisian coasts: update and distributional ecology. Marine Biodiversity Records, 2, e155.

DOI: $10.1017 / \mathrm{S} 1755267209990820$

http://journals.cambridge.org/action/displayAbstract?fromPage $=$ online\&aid $=6450876 \&$ fileId $=$ S1755267209990820

19 Lucena-Moya, P., Abraín, R., Pardo, I., Hermida, B. \& Domínguez, M. (2010) Invertebrate species list of coastal lagoons in the Balearic Islands. Transitional Waters Bulletin, 4(1), 1-11.

DOI: $10.1285 / \mathrm{i} 1825229 \mathrm{Xv} 4 \mathrm{n} 1 \mathrm{p} 1$

http://siba-ese.unisalento.it/index.php/twb/article/view/11527

20 Sezgin, M. \& Aydemir Çil, E. (2010) Rocky bottom crustacean fauna of Sinop (Black Sea, Turkey) coast. Zoologica Baetica, 21, 5-14. http://www.ugr.es/ zool_bae/vol21/Zoo-1\%20Sezgin.pdf

21 Jelassi, R., Khemaissia, H. \& Nasri?Ammar, K. (2012) Intra?annual variation of the spatiotemporal distribution and abundance of Talitridae and Oniscidea (Crustacea, Peracarida) at Bizerte Lagoon (northern Tunisia). African Journal of Ecology, 50(4), 381-392.

DOI: $10.1111 /$ j.1365-2028.2012.01326.x

http://onlinelibrary.wiley.com/doi/10.1111/j.1365-2028.2012.01326.x/full

22 Jelassi, R. \& Nasri-Ammar, K. (2012) Temporal variation in the shore amphipod community in the supralittoral zone of Bizerte Lagoon (northern Tunisia). Crustaceana, 85(4-5), 433-446.

DOI: $10.1163 / 156854012$ X636706

http://booksandjournals.brillonline.com/content/journals/10.1163/156854012x636706

23 Bakir, K. (2012) Contributions to the knowledge of crustaceans on soft bottoms in the Sea of Marmara, with a checklist. Crustaceana, 85(2), 219.

DOI: $10.1163 / 156854012 X 626437$

http://booksandjournals.brillonline.com/content/journals/10.1163/156854012x626437\%3Fcrawler\%3Dtrue

24 Pavesi, L. \& Ketmaier, V. (2013) Patterns of genetic structuring and levels of differentiation in supralittoral talitrid amphipods: an overview. Crustaceana, 86(7-8), 890-907.

DOI: $10.1163 / 15685403-00003212$

http://booksandjournals.brillonline.com/content/journals/10.1163/15685403-00003212

25 Lowry, J.K. \& Fanini, L. (2013) Substrate dependent talitrid amphipods from fragmented beaches on the north coast of Crete (Crustacea, Amphipoda, Talitridae), including a redefinition of the genus Orchestia and descriptions of Orchestia xylino sp. nov. and Cryptorchestia gen. nov. Zootaxa, 3709 (3), 201-229.

DOI: 10.11646/zootaxa.3709.3.1

http://www.biotaxa.org/Zootaxa/article/view/zootaxa.3709.3.1/0

26 Jelassi, R., Zimmer, M., Khemaissia, H., Garbe-Schönberg, D. \& Nasri-Ammar, K. (2013) Amphipod diversity at three Tunisian lagoon complexes in relation to environmental conditions. Journal of Natural History, 47(45-46), 2849-2868. DOI:10.1080/00222933.2013.792960 http://www.tandfonline.com/doi/abs/10.1080/00222933.2013.792960

27 Christodoulou, M., Paraskevopoulou, S., Syranidou, E. \& Koukouras, A. (2013) The amphipod (Crustacea: Peracarida) fauna of the Aegean Sea, and comparison with those of the neighbouring seas. Journal of the Marine Biological 
Association of the United Kingdom, 93(05), 1303-1327.

DOI: $10.1017 / \mathrm{S} 002531541200183 \mathrm{X}$

http://journals.cambridge.org/action/displayAbstract?fromPage $=$ online\&aid=8951412\&fileId $=$ S002531541200183X

28 Karaman, G.S. (2014) On some gammaridean amphipods from western Balkan peninsula (contribution to the knowledge of the Amphipoda 275). Agriculture and Forestry, 60(2), 207-232.

http://www.cabdirect.org/abstracts/20143303745.html;jsessionid=B015B8D570FF370A5AE00ADA4DFA22DF

29 Jelassi, R., Khemaissia, H., Zimmer, M., Garbe-Schönberg, D. \& Nasri-Ammar, K. (2015) Biodiversity of Talitridae family (Crustacea, Amphipoda) in some Tunisian coastal lagoons. Zoological Studies, 54(1), 17.

DOI 10.1186/s40555-014-0096-1

http://www.biomedcentral.com/content/pdf/s40555-014-0096-1.pdf

30 Scapini, F., Gambineri, S., Rossano, C., ElGtari, M., Fanini, L. \& Nourisson, D.H. (2015) Talitrid orientation as bioindicator of shoreline stability: Protected headland-bays versus exposed extended beaches. Ecological Indicators, 53, $28-36$.

DOI:10.1016/j.ecolind.2015.01.012

http://www.sciencedirect.com/science/article/pii/S1470160X15000138 